\title{
Documentos CEDE
}

ISSN 1657-7191 edición electrónica

The Monetary Foundation of the Economic Circuit and the Principle of Effective Demand in Marx, Keynes and Kalecki

\section{Hernando Matallana}


Serie Documentos Cede, 2008-24

ISSN 1657-7191

Noviembre de 2008

(C) 2008, Universidad de los Andes-Facultad de Economía-Cede

Carrera 1 No. 18 A - 12, Bloque C.

Bogotá, D. C., Colombia

Teléfonos: 3394949- 3394999, extensiones 2400, 2049, 2474

infocede@uniandes.edu.co

bttp:/ / economia.uniandes.edu.co

Ediciones Uniandes

Carrera 1 No. 19 - 27, edificio Aulas 6, A. A. 4976

Bogotá, D. C., Colombia

Teléfonos: 3394949- 3394999, extensión 2133, Fax: extensión 2158

infeduni@uniandes.edu.co

http:/ / ediciones.uniandes.edu.co/

Edición, diseño de cubierta, preprensa y prensa digital:

Proceditor ltda.

Calle 1C No. 27 A - 01

Bogotá, D. C., Colombia

Teléfonos: 2204275, 220 4276, Fax: extensión 102

proceditor@etb.net.co

Impreso en Colombia - Printed in Colombia

El contenido de la presente publicación se encuentra protegido por las normas internacionales y nacionales vigentes sobre propiedad intelectual, por tanto su utilización, reproducción, comunicación pública, transformación, distribución, alquiler, préstamo público e importación, total o parcial, en todo o en parte, en formato impreso, digital o en cualquier formato conocido o por conocer, se encuentran prohibidos, y sólo serán lícitos en la medida en que se cuente con la autorización previa y expresa por escrito del autor o titular. Las limitaciones y excepciones al Derecho de Autor, sólo serán aplicables en la medida en que se den dentro de los denominados Usos Honrados (Fair use), estén previa y expresamente establecidas; no causen un grave e injustificado perjuicio a los intereses legítimos del autor o titular, y no atenten contra la normal explotación de la obra. 


\title{
THE MONETARY FOUNDATION OF THE ECONOMIC CIRCUIT AND THE PRINCIPLE OF EFFECTIVE DEMAND IN MARX, KEYNES AND KALECKI
}

Hernando Matallana, October $2008^{1}$

\begin{abstract}
Marx carried out the first full inquiry on the economics of the all-comprising circulation process of capital, first in Grundrisse in the late 1850s, and later in Capital and Theories of Surplus Value in the 1860s and the 1870s. Two substantial aspects are at the center of Marx's analysis: (a) the monetary determination of the social process of production and circulation of capital, i.e. the fact that money-capital is a social relation determining the interaction of agents in the monetary production economy alias capitalism; and (b) the notion of the economic circuit as the key economic category for the understanding of the monetary logic of the principle of effective demand. These aspects are also at the center of Keynes's and Kalecki's foundation of the theory of the monetary production economy.
\end{abstract}

\section{Key Words}

Accounting dynamics, capital, circulation process, effective demand, input-output analysis, Marx, monetary production economy

\section{JEL Classification:}

$\mathrm{B} 14, \mathrm{~B} 22, \mathrm{E} 40$

\footnotetext{
${ }^{1}$ I am grateful to Jimena Hurtado, Samuel Jaramillo and Alvaro Moreno for their suggestions and comments on earlier drafts. I am also specially in debt to Sanjay Fernandes. All remaining errors are mine. Lecturer, School of Economics, Universidad de los Andes, E-mail: hmatalla@uniandes.edu.co.
} 


\section{Resumen}

Marx llevó a cabo la primera investigación comprensiva de la lógica económica del proceso de circulación del capital, primero en los Elementos fundamentales a finales de la década de 1850, y más tarde en El capital y Teorías de la plusvalía en las décadas de 1860 y 1870. Dos aspectos sustanciales se hallan en el centro del análisis de Marx: (a) la determinación monetaria del proceso social de producción y circulación del capital, es decir, el hecho de que el capital-dinero es una relación social que determina la interacción de los agentes económicos en una economía monetaria de producción alias capitalismo; y (b) la noción del circuito económico como la categoría económica clave para la comprensión de la lógica monetaria del principio de la demanda efectiva. Estos dos aspectos también se encuentran en el centro de la fundamentación teórica de la teoría de la economía monetaria de producción en la obra de Keynes y Kalecki.

\section{Palabras clave}

Análisis insumo-producto, capital, demanda efectiva, dinámica contable, economía monetaria de producción, Marx, proceso de circulación

\section{Clasificación JEL:}

B14, B22, E40 


\section{The monetary foundation of the economic circuit and the principle of effective demand in Marx, Keynes and Kalecki}

\section{Contents}

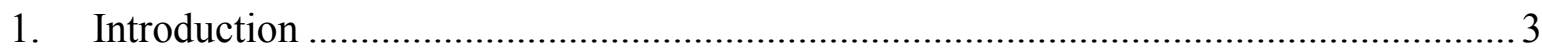

2. Marx's theory of the circulation process of capital in "Das Kapital" ......................... 9

2.1. The theoretical foundation of the circulation process ......................................... 9

2.2. The functional conditions of production and circulation ................................ 11

2.3. The long-run equilibrium of simple and extended reproduction ........................ 15

2.4. The process of circulation and the principle of effective demand....................... 16

3. Final remarks - Marx, Keynes and Kalecki ......................................................... 20

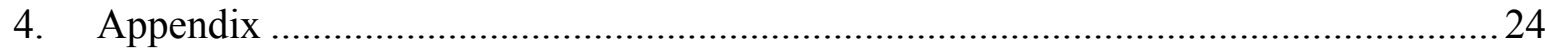

4.1. Marx's input-output matrices of simple reproduction ......................................24

4.2. The accounting dynamics of simple reproduction of a capitalistic economy....... 27

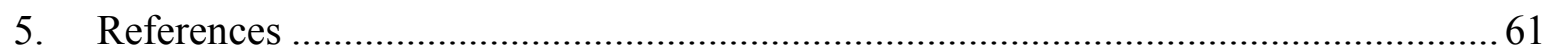

\section{Introduction}

Marx carried out the first full inquiry on the economics of the all-comprising circulation process of capital a century after the publication of Cantillon's Essay in 1755 and Quesnay's Tableau économique in 1758-1766. First he discussed it in Grundrisse in the late 1850s, and later in Capital and Theories of Surplus Value in the 1860s and the 1870s.

Marx's main intellectual source was Quesnay's analysis of the circuite économique of the agricultural kingdom, not Smith's nor Ricardo's classical political economy. His prodigous comment on Quesnay's work in the Theories of surplus value and Capital reasserts the scientific relevance of the physiocratic notion of the economic circuit for the theoretical determination of the economic logic of capitalism. In volume I of Theories of surplus value he writes: 
"The analysis of capital, within the bourgeois horizon, is essentially the work of the Physiocrats. It is this service that makes them the true fathers of modern political economy." (italics in the original version) [Marx (1965, 1861-1863): vol. I, chap. 2]

"As regards the circulation of capital-its reproductive process, the various forms which it assumes in this process of reproduction, the connection between the circulation of capital and circulation in general (that is, not only the exchange of capital for capital, but of capital for revenue)_-Adam Smith in fact only took over the inheritance of the Physiocrats and classified and specified more precisely the separate items in the inventory. But his exposition and interpretation of the movement as a whole was hardly as correct as its presentation in outline in the Tableau économique, in spite of Quesnay's false assumptions." [Marx (1965, 18611863): vol. I, chap. 6]

The main theoretical issues discussed by Marx, and before him by Quesnay, when considering the circulation process were later addressed in the late $19^{\text {th }}$ century by orthodox marxists, in the 1920s and 1930 s by Kalecki and Keynes, and in the $20^{\text {th }}$ century by postKeynes-Kalecki economists. Orthodox marxists, post-Leontief neoclassical authors, the neoricardians, Keynes, Kalecki, and post-Keynes-Kalecki economists of sorts-AngloAmerican Post-Keynesians, Italo-French Circuitists and German Monetary-Keynesianshave praised Marx's genuine discussion of the social process of circulation of a capitalist economy on different reasons, both theoretical and ideological. However, the consideration of the social process of circulation in a capitalistic economy as a monetary process has been a subject matter of theoretical reflection mainly of heterodox economists.

Marx's analysis accounted for the demand-led equilibrium and disequilibrium macrodynamics of a capitalistic economy in the context of the theory of labour value. The discussion of the interdependence of the proces of production and circulation of an economy characterized by the circular production of commodities by means of commodities both at the aggregate and the sectorial levels led him to set up the first inputoutput matrix in the history of economic ideas. ${ }^{2}$ All these were impressive achievements by themselves, particularly at a time when national accounting, effective demand, input-output analysis, inter-industrial steady state economics, and balanced growth equilibrium theory

\footnotetext{
${ }^{2}$ This particular issue is addressed in section 4.1 of the appendix.
} 
had not yet been invented, except by Quesnay's genius, for which “one can claim immortal fame for Marx" (Samuelson 1977). ${ }^{3}$

Two substantial aspects are at the center of Marx's analysis of the circulation process: (a) the monetary determination of the social process of production and circulation of capital, i.e. the fact that money-capital is a social relation determining the interaction of agents in the monetary production economy alias capitalism; and (b) the notion of the economic circuit as the key economic category for the understanding of the monetary logic of the principle of effective demand. These two aspect are also at the center of Keynes's and Kalecki's theory of a monetary production economy.

The heterodox theory of the monetary production economy asserts the substantial determination of money as the medium of deferred payments, the endogeneity of money, and the non-neutrality of money vis-à-vis the economic process both in the short run and the long run. Money is thus the a priori essential, non-neutral economic category without which the understanding of the motion laws of capitalism is not possible.

Moreover, a theory of the monetary production economy in which money is both endogenous and essential implies the principle of effective demand. Incidentaly, all the heterodox authors that have discussed the all-comprising capitalistic process of circulation of capital determine money as a medium of deferred payments, i.e. the mercantilists, the physiocrats, Marx, Kalecki and Keynes, and post-Keynes-Kalecki economists of sorts.

In particular, Marx, Keynes, and Kalecki show in their theoretical work that the principle of effective demand implies a specific form of social organization in which the money capitalwage labour relation is sistematically reproduced through the reproduction of the social and material conditions of the production process and the circulation process of capital as a

\footnotetext{
${ }^{3}$ Samuelson (1977) considers that Marx's main scientific contribution to political economy is his seminal analysis of inter-industrial steady state and balance growth equilibrium, despite of it being formulated in terms of the classical labour theory of value. (Orthodox marxists disagree with Samuelson's dismissal of the labour-value theory. The point is irrevelant for the purpose of the paper, yet.) Samuelson is right insofar Marx's theory of circular production and steady growth is one of his theoretical contributions to political economy. However, Samuelson's appraisal of Marx's analysis of the social process of circulation of capital, and more generally of the reproduction of capital as a social relation, is too narrow in a fundamental sense both theoretically and analytically.
} 
monetary process. Their analysis also shows that the monetary logic of the principle of effective demand only becomes intelligible provided the accounting dynamics of the circulation process of money and commodities in a monetary production economy is fully stated. $^{4}$

By contrast, orthodox classical-neoclassical economists never carried out a rigorous discussion of the social process of circulation of money and commodities. ${ }^{5}$

This is not surprising in the case of the neoclassical general equilibrium, it being the theoretical concept of a centralized economy with complete markets and perfect information. In this economy there is simply no room for money either as the unit of account, the general means of exchange, the store of value, or the medium of deferred payments. The prices of the goods and the factors of production, hence of labour, are either accounting prices or relative prices, not money prices.

Hahn commented more than two decades ago on the neglection of money and the circulation/allocation process in the Arrow-Debreu economy:

"The most serious challange that the existence of money poses to the theorist is this: the best developed model of the economy cannot find room for it. The best developed model is, of course, the Arrow-Debreu version of a Walrasian general equilibrium. A world in which all conceivable contingent future contracts are possible neither needs nor wants intrinsically worthless money."[Hahn (1982): 1]

\footnotetext{
${ }^{4}$ This is true irrespective of whether the analysis of the economic process is developed in terms of the labour theory of value as in Marx's Capital, or as in the terms of a monetary theory of value as in Keynes's and Kalecki's theory of the monetary production economy. However, it is the opinion of the author of the paper that, stricto sensu, the scientific foundation of the monetary logic of the principle of effective demand is only possible in the context of a monetary theory of value, distribution and money as intended by Keynes, Kalecki, and post-Keynes-Kalecki heterodox authors. A thorough discussion of a monetary theory of value and distribution is beyond the scope of the paper. See Riese (2001), vol. I.; Betz (1987). See section 4.2 of the appendix on the accounting dynamics of the capitalistic process of circulation.

${ }^{5}$ E.g. Walras's critique of Quesnay's physiocratique docrine in lesson 37 in section VII of Elements of pure economics (Walras 1954) negates altogether the role of money as medium of deferred payments and as means of exchange. The evacuation of money in Walras's analysis implies the negation of the mediation of exchange by the circulation of money. Hence the process of exchange is conceived as a process of barter between the three functional classes of the royaume agricole implying the Say's law. Yet, Walras's discussion voids Quesnay's analysis of its specific scientific moment, i.e. the monetary conception of the economic circuit and the principle of effective demand. Mutatis mutandi, the same is true of Samuelson's discussion of Marx's analysis of the capitalistic process of circulation in volume II of Capital (Samuelson 1977), and of Quesnay's analysis of the circuit economic in the Tableau Économique (Samuelson 1982), too. Samuelson follows unknowlingly (sic) Walras on this issue, both methodologically and theoretically.
} 
"Certainly the Arrow-Debreu economy has no medium of exchange and has great difficulties in accomodating one; but it is not a barter economy either. That is because neither the process nor the technology of exchange is described and because it makes no sense to ask in this connection what does A exchange against what with whom in order to reach his allocation."'[Hahn (1985): 32]

On the other hand, monetary classical and neoclassical authors, and mainstream economists as well, both old and new, assert the economic determination of money as the means of exchange, the exogeneity of money, and the neutrality of money vis-à-vis the economic process (in the long run). This orthodox determination of money conveys the theoretical validity of Say's law, i.e. "Supply creates its own demand", for any level of employment. Under competitive conditions, the working of supply on demand leads the economy in the long-run to a full-employment position. Yet, as Keynes noted in the General Theory:

"If, however, this [i.e. Say's law] is not the true law relating the aggregate demand and supply functions, there is a vitally important chapter of economic theory which remains to be written and without which all discussions concerning the volume of aggregate employment are futile."[Keynes (1936): 26] (square brackets added)

Before Keynes, Marx had already addressed this point in Book IV of the Grundrisse when commenting critically the tension between Ricardo's political economy of production (which Ricardo considered in itself without regard of demand), and Sismondi's (and Malthus's) political economy of effective demand (which Sismondi considered mainly in relation to the possibility of economic crises), as a specific inner contradiction of capital.

"Those economists who, like Ricardo, conceived production as directly identical with the self-realization of capital and hence were heedless of the barriers to consumption or of the existing barriers of circulation itself, to the extent that it must represent counter-values at all points, having in view only the development of the forces of production and the growth of the industrial population supply without regard to demand have therefore grasped the positive essence of capital more correctly and deeply than those who, like Sismondi, emphasized the barriers of consumption and of the available circle of counter-values, although the latter has better grasped the limited nature of production based on capital, its negative onesidedness. The former more its universal tendency, the latter its particular restrictedness. The whole dispute as to whether overproduction is possible and necessary in capitalist production revolves around the point whether the process of the realization of capital within production directly posits its realization in circulation; whether its realization posited in the production process is its real realization. Ricardo himself, of course, has a suspicion that the exchange value of a commodity is not a value apart from exchange, and that it proves itself as a value only in exchange; but he regards the barriers which production thereby encounters 
as accidental, as barriers which are overcome. He therefore conceives the overcoming of such barriers as being in the essence of capital, although he often becomes absurd in the exposition of that view; while Sismondi, by contrast, emphasizes not only the encounter with the barriers, but their creation by capital itself, and has a vague intuition that they must lead to its breakdown. He therefore wants to put up barriers to production, from the outside, through custom, law etc., which of course, as merely external and artificial barriers, would necessarily be demolished by capital. On the other side, Ricardo and his entire school never understood the really modern crises, in which this contradiction of capital discharges itself in great thunderstorms which increasingly threaten it as the foundation of society and of production itself." [Marx 1983b, 1857-58): Book IV, Part II]

The neglection by classical-neoclassical authors of the scientific need of the theoretical reflection of the circulation process of capital as a monetary process might be the main reason of the long standing difficulty of orthodox economists to grasp the true economic substance of the principle of effective demand as a key notion for the understanding of the monetary dynamics of capitalism.

Mutatis mutandi, the same might be said of the mainstream (anti-heterodox) macroeconomic theories that came into existence after the publication of Keynes's General Theory, i.e. Pigouvian (classical) macroeconomics, IS-LM keynesianism, monetarism, neoclassical synthesis, new Keynesianism, new classical economics, real business cycle economics and Austrian economics. ${ }^{6}$

Hence Marx's reflection of the monetary process of circulation of capital, as well as Keynes's and Kalecki's, conveys a substantial critique of one-sided orthodox/mainstream economics. This is certainly the negative contention of the article.

The remaining sections of the article are organized as follows. Section 2 discusses Marx's analysis of the social process of circulation of capital and the principle of effective demand in volume II of Capital. Section 3 contains some final remarks on Marx, Keynes and Kalecki on the principle of effective demand in a monetary production economy. The appendix in section 4 presents several simple-reproduction input-output matrices developed by Marx in the Grundrisse and in volume II of Capital. The appendix also contains the

\footnotetext{
${ }^{6}$ See Snowdon et al. (1994) for an overview of meanstream macroeconomic theories after the publication of Keynes's General Theory in 1936.
} 
accounting dynamics of a particular simple-reproduction input-output matrix in volume II of Capital in terms of a system of credit-debit tables currently used by German authors.

\section{Marx's theory of the circulation process of capital in "Das Kapital"}

Marx made a great step towards a theory of the circulation process once he restated Quesnay's Tableau économique (1991) in terms of the economic categories of a capitalistic

society. This lead him to the formulation of the monetary logic of both the all-comprising process of circulation of social capital and the principle of the effective demand in section III of volume II of Capital.

It is Marx's main contention in section III of volume II of Capital that the comprehension of the true economic dynamics of capitalism requires the full consideration of the accounting dynamics of the circulation process of money and commodities between the functional agents and the productive sectors of the capitalist economy. It follows from Marx's analysis that the economic logic of the principle of effective demand implies a monetary theory of capitalism.

2.1. The theoretical foundation of the circulation process

Marx analyses first in sections I and II of volume II of Capital the distinct moments of the process of circulation of capital in the framework of the labour theory of value. Later in section III he considers the social process of circulation of capital altogether.

There he determines primarily: i) the particularization of constant and variable capital in the circulation process into fixed capital and circulating capital; ii) the particularization of capital into the distinct individual capitals in the different branches of production that imply the social division of labour; iii) the interdependence of production and circulation at the individual, sectorial and aggregate levels implied in the system of social division of labour; iv) the input-output relation of the circular production between the diverse productive 
sectors; v) the particularization of the aggregate demand in consumption and investment, and the important of the structure of demand in determining the productive structure of the economy; vi) the central role of aggregate demand in determining income and employment in the economy; vii) the intertwining of the individual capitals in the social process of production and circulation of capital considered as a whole; viii) the function of money as a means of deferred payments, means of purchase and reserved of value in the circulation process; ix) the interrelation of the functional classes of the capitalist economy; and $\mathrm{x}$ ) the systematic reproduction of social and economic relations in the circulation process characteristic of the capitalist society.

The determination of the social process of circulation of capital considered as a whole demands the consideration of the intertwining of individual capitals. This is the subject matter of theoretical reflection in section III of Capital's volume II:

"However the circuits of the individual capitals intertwine, presuppose and necessitate one another, and form, precisely in this interlacing, the movement of the total social capital. Just as in the simple circulation of commodities the total metamorphosis of a commodity appeared as a link in the series of metamorphoses of the world of commodities, so now the metamorphosis of the individual capital appears as a link in the series of metamorphoses of the social capital. ... We have now to study the process of circulation (which in its entirety is a form of the process of reproduction) of the individual capitals as components of the aggregate social capital, that is to say, the process of circulation of this aggregate social capital." [Marx (1983a, 1885): vol. II, part III, chap. 18]

The analysis of the process of the circulation of money and commodities as a social process constitutes an essential moment in the theoretical determination of the economic logic of money capital-wage labour relation. In Marx's sense capital is a social relation which produces and reproduces the functional conditions, both social and material, under which both the process of production and the process of circulation take place. To such extent, it fixes the general conditions under which the production and reproduction the functional economic classes within the capitalist society takes place.

The capitalist society for which Marx develops the analysis of the economic circuit is divided in two functionally distinct social classes: the working class and the capitalist class. The working class is unfolded into the wage-workers and the working households. In turn, the capitalist class is particularized into functionally distinct economic agents: the firms or 
industrial capitalists, the capitalist households (that is, capitalists as consumers), the banking system and the wealth-owners. ${ }^{7}$

Marx states precisely this point:

"If we study the annual function of social capital - hence of the total capital of which the individual capitals form only fractional parts, whose movement is their individual movement and simultaneously integrating link in the movement of the total capital - and its results, i.e., if we study the commodity-product furnished by society during the year, then it must become apparent how the process of reproduction of the social capital takes place, what characteristics distinguish this process of reproduction from the process of reproduction of an individual capital, and what characteristics are common to both. The annual product includes those portions of the social product which replace capital, namely social reproduction, as well as those which go to the consumption-fund, those which are consumed by labourers and capitalists, hence both productive and individual consumption. It comprises also the reproduction (i.e., maintenance) of the capitalist class and the working-class, and thus the reproduction of the capitalist character of the entire process of production.’[Marx (1983a, 1885): vol. II, part III, chap. 20]

\subsection{The functional conditions of production and circulation}

Following Marx, the general movement of (industrial) capital can be expressed through the following formula:

\footnotetext{
${ }^{7}$ Marx discusses fragmentarily in volume II of Capital the creditor-debtor relation between the different functional agents that taken altogether constitute the capitalist class. The analysis of the monetary and financial system, the particularization of the banks into the central bank and the business banks, the banking credit and the (endogenous) process creation of money, the relation between the banking system, the industrial capitalists, and the capitalist wealth-owners is not (fully) developed. The lack of a precise determination of the functional division of the economic agents within the capitalist class and of the system of the monetary and financial marktes in volume II is explained by the fact that the dialectical development of these categories belongs to volume III (sections IV and V) of Capital. The production process of capital is reflected critically in volume I of Capital, while the analysis of the circulation process takes place in volume II. The unity of both the production process and the circulation process was intended to be the subject matter of volume III. In particular, the writing plan of Capital foresees the development of the economic categories of a theory of money in volume III. See Marx (1983b); Marx (1893a, 1894). Marx did not complete this volume, and the fragmentary manuscripts were edited and published after his death by Engels in 1894. See Betz (1987) on this particular point.
} 


$$
D-D-\left\{\begin{aligned}
m p & \\
f t & \cdots \text { Producci- } n \cdots x
\end{aligned}\right\}-D^{\prime}-D^{\prime}
$$

where $D$ is the initial capital-money, $m p$ - the means of production, $f t$ - the labour force, $x$ - the commodity-product and $D^{\prime}$ - the end sum of money that the capitalist expects to obtain after the sale of his commodity. ${ }^{8}$

The forms assumed during the economic process by any individual capital and, to that extent, by the capital of society as a whole, the latter being the sum of the individual capitals, are: (i) money-capital, i.e., money to be advanced as capital; (ii) productive capital, i.e., the constant capital equal to the value means of production and the variable capital equal to the value of the labour power; and (iii) commodity-capital, i.e., the result of the production process, whose value encloses the constant capital, the variable capital and surplus value created by the labour power during the process of production itself. The consolidated balance of the creditor-debtor relations between the distinct functional agents summarizes the diverse forms that capital takes during the economic process involving the production and circulation of money and commodities. ${ }^{9}$

\footnotetext{
${ }^{8}$ The external relation $D-D^{\prime}$ reflects the interest-lending of money by the banks to the industrial capitalists. To Smith, Ricardo and Marx, the money rate of interest is determined by the rate of profits, whilst the latter is equal to the subsistence wage rate. Hence in the context of classical political the external relation $D-D$ ' plays no essential role in the determination of the process of production and circulation of capital. By contrast, in Keynes's monetary production economy the money rate of interest determines the rate of profit and ultimately the real wage rate. Hence money as represented in the external relation $D-D$ ' plays a substantial part in the determination of the economic process of a monetary production economy. Marx did not fully develop the notion of money-capital as represented by the external relation $D-D$ ' in volume III of Capital. See Betz (1987).

9 The business accounting permits the industrial capitalist to supervise the dynamics of the different components of its capital: its division into money, means of production, labour, finished and unfinished product; the subdivision of the means of production into fixed and working capital; the beginning, the duration and the end of the simultaneous, overlapping and sequential processes of production and circulation; the intertwining and interdependence of his own capital with the capital of other industrial capitalists, etc. "As unity within its circuits, as value in motion, whether in the sphere of production or in either phase of the sphere of circulation, capital exists ideally only in the form of money of account, primarily in the mind of the producer of commodities, the capitalist producer of commodities. This movement is fixed and controlled by book-keeping, which includes the determination of prices, or the calculation of the prices of commodities. The movement of production, especially of the production of surplus-value - in which the commodities figure only as depositories of value, as the names of things whose ideal existence as values is crystallised in money of account — thus is symbolically reflected in imagination."[Marx (1983a, 1885): vol. II, part I, chap. 6]
} 
Marx assumes in volume II of Capital that the industrial capitalists have at their disposal the money required for the production process and the circulation process to take place under normal circumstances, i.e. in the long-run (stationary-state and steady-state) equilibrium. Both the transformation of money into the means of production and the labour power (capital-commodity), as well as the transformation of the end product into money (commodity-capital), take place in the sphere of circulation. By contrast, the productive consumption, i.e., the transformation of the means of production and the labour into the final product, takes place in the sphere of production.

The unity of these three moments circulation (purchase of labour power and capital goods)production (surplus value)-circulation (product sale) completes the full movement of the industrial capital. The greater or lesser continuity of the production of commodities makes capital be always divided between money, means of production, labour (paid ante festum), and commodity-product in always changing proportions. The exact division of capital into these three particular forms at any given moment of time depends on the particular circumstances under which either the production process and circulation process take place. These circumstances can always be modified in a greater or lesser degree as a consequence of the alteration in the general condition of supply and demand.

In the framework of the labour theory of value, the productive capital particularizes into constant capital, i.e. the value of the means of production, and variable capital, i.e. the value of labour power. This holds for the individual capital, but also for capital at the sectoral level and the capital of society considered as a whole. The labour power involved in the variable capital is the source of surplus value, yet, the ownership of capital by the capitalist class confers the latter the right to appropiate the surplus value produced by the variable capital, i.e. by the labour-power under the command of capital. ${ }^{10}$

In turn, in the analysis of the circulation process, these two forms of capital particularize into fixed capital and circulating capital. Hence the constant capital is divided into the fixed constant capital and the circulating constant capital, whereas the variable capital belongs

\footnotetext{
${ }^{10}$ Marx states the precise definitions of variable and constant capital in section II of volume I of Capital; see also chapter 20.II of volume II.
} 
altogether to the circulating capital. In particular, the reflection of the annual circulation process of capital requires the consideration of depreciation of fixed capital.

In section III of volume II of Capital Marx assumes that the economy contains two different industries. The first industry produces means of production to be used as means of production in both industries. The second industry produces consumer goods. In turn, the consumer goods industry is divided into an industry of basic consumption commodities (subsistence goods/necessaries) and an industry of luxury commodities. ${ }^{11}$ Marx assumes free competition both within and between the two different industries, hence there is free mobility of capital and labour throughout the economy. Generally, the accounting dynamics of the economic circuit does not imply a particular market structure. Further, Marx assumes equal organic composition of capital throughout the economy. ${ }^{12}$

On the other hand, the final demand is divided into the final consumption of the households and the investment of the firms. Marx assumes that the working households only consume subsistence goods, and the capitalist households consume both subsistence and luxury goods. This gives way to a subdivision within the consumer goods industry.

Marx also assumes that the the wage income of the individual worker is equal to the value of its labour power. Accordingly, the working households spend fully the wage income to buy subsistence commodities, hence, they do not save.

The division of the final demand of the capitalist class in the consumer demand of the capitalist households and the investment of the industrial capitalists (i.e the firms) allows for two different cases: (i) simple reproduction: the capitalist households purchase consumer goods, the value of which is equal to their income, and the firms do not invest; and (ii) extended reproduction: the households consume (and save), and the firms buy

\footnotetext{
${ }^{11}$ The set of techniques of production described by Marx implies the circular production of commodities by means of commodities. Accordingly, the first industry produces 'basics' and the second produces 'nonbasics'. See Sraffa (1960).

${ }^{12}$ This assumption allows Marx to skip the theoretical and analytical difficulties that entails the consideration of the transformation of labour values into prices of production. The analysis of the circulation process does not presuppose the consideration of the so-called 'tranformation problem'. The latter is the subject matter of volume III of Capital. See Marx (1983a, 1894); also Sraffa (1960).
} 
newly produced means of production, hence, the extended reproduction conveys the accumulation of capital. These two cases are discussed, respectively, in chapter 20 and chapter 21 in section III of volume II of Capital.

\subsection{The long-run equilibrium of simple and extended reproduction}

The economy is in long-run equilibrium whenever the level and structure of the ex ante demand of the households and the firms corresponds to the level and structure of the ex ante supply of the firms. In the framework of the theory of labour value, this implies that market prices correspond to the labour-values of the commodities in all markets, provided equal organic composition of capital is assumed throughout the economy. Under the extreme assumption of equal organic compositions the equilibrium prices are equal to the labour-values and equal to the production prices. Also, the long-run equilibrium conveys a monetary equilibrium in the sense that the dynamics of the velocity of circulation of money and the amount of money in the economy does not imply an alteration in the general level of prices.

The assumption of simple reproduction corresponds to the analysis of the economic circuit of Quesnay's agricultural kingdom. In this case, the long-term stationary state equilibrium implies that the prices and the quantities do not change. ${ }^{13}$ In the simple-reproduction or stationary state case, the investment equals zero. This can be justified by assuming that the actual stock of capital of the economy corresponds to the long-run optimal/equilibrium stock. Moreover, the long-run stationary state equilibrium requires the consumption expenditure of the households to be equal to the income of the economy, the savings of both the capitalist class and the working class being equal to zero. ${ }^{14}$

\footnotetext{
${ }^{13}$ The stationary state in the classical sense conveys a zero growth rate of the economy.

14 Marx was fully aware that the simple-reproduction assumption is heuristic in character: "Simple reproduction, reproduction on the same scale, appears as an abstraction, inasmuch as on the one hand the absence of all accumulation or reproduction on an extended scale is a strange assumption in capitalist conditions, and on the other hand conditions of production do not remain exactly the same in different years (and this is assumed)."[Marx (1983a, 1885): vol. II, part III, chap. 20]
} 
A process of accumulation in which the ex ante savings of the households corresponds to the ex ante investment of the firms constitutes a dynamic equilibrium. The special case of a dynamic equilibrium with a uniform positive growth rate and non changing prices is a longrun steady state equilibrium. The mismatch of the ex ante aggregate demand and the ex ante supply gives way to off-equilibrium market processes. ${ }^{15}$

As in Quesnay's Tableau économique, the analysis of the circulation process of capital in volume II of Capital consists only of the accounting dynamics of the aggregate monetary flows of the economy. At the starting point of the analysis of the circulation process, the social capital, i.e. the sum total of capital of society, appears under the form of both moneycapital and (produced) commodity-capital, it being the result and the precondition of the process of (circular) production. In the circulation process the commodity-capital is demanded either as a means of production or as consumption good, while the labour power is incorporated into capital as variable capital, i.e. as a source of surplus value.

Marx carries out the discussion of the circulation process of capital in the framework of the so-called simple and extended "schemes of reproduction". Marx's schemes of reproduction convey alternative post-Leontief input-output matrices, though they are formulated in terms of labour values. ${ }^{16}$

2.4. The process of circulation and the principle of effective demand

The development of the circulation process requires the firms to have at their disposal the money needed to pay the money income to the factors of production, and to purchase the

\footnotetext{
${ }^{15}$ See Marx (1885), vol. II, chap. XXI; also Samuelson (1977, 1974).

${ }^{16}$ Marx's reproduction schemes convey an open Leontief input-output matrix. Marx developed the inputoutput matrix in terms of aggregate monetary flows in the 1850s and 1860s, first in the Grundrisse (Marx 1983b) and later in volume II of Capital (1983a). See section 4.1 in the appendix on Marx's input-output matrices.
} 
means of production. This is assumed by Marx to be warranted. In sense this amounts to assume that the firms are their own bankers. ${ }^{17}$

The firms pay the wages to the workers and the working households spend their wage in basic consumer commodities. The consumption expenditure of working households implies that the money paid to the workers under the form of the wages flows back in a greater or lesser degree to the hands of the capitalist class. Marx notes on this particular point:

"However, the money-capital converted into variable capital, i.e., the money advanced for wages, plays a prominent role in the circulation of money itself, since the labourers must live from hand to mouth and cannot give the industrial capitalists credit for any length of time. For this reason variable capital must be advanced in the form of money simultaneously at innumerable territorially different points in society at certain short intervals, such as a week, etc.- - in periods of time that repeat themselves rather quickly (and the shorter these periods, the smaller relatively is the total amount of money thrown at one time into circulation through this channel)whatever the various periods of turnover of the capitals in the different branches of industry. In every country with a capitalist production the money-capital so advanced constitutes a relatively decisive share of the total circulation, the more so as the same money, before its reflux to its point of departure, passes through the most diverse channels and functions as a medium of circulation for countless other businesses." [Marx (1983a, 1885): vol. II, part III, chap. 20]

If, as Marx supposes, the value of the consumption expenditure of working households is equal to the wage income, then all the money paid as money wages by the firms flows back to the latter under the form of the consumption expenditure of the working households. In this case, the remainder of the wage payment and the consumption expenditure of labour households equals zero. It follows that in the aggregate the consumption expenditure of the working class does not determine in any way the realization of the surplus value of the firms considered as a whole. However, the savings of the working class reduce the surplus

\footnotetext{
${ }^{17}$ In section V of chapter XX of volume II of Capital Marx states: "if any money-capitalist at all stands behind the producer of commodities and advances to the industrial capitalist money-capital (in the strictest meaning of the word, i.e., capital-value in the form of money), the real point of reflux for this money is the pocket of this money-capitalist. Thus the mass of the circulating money belongs to that department of moneycapital which is organised and concentrated in the form of banks, etc., although the money circulates more or less through all hands. The way in which this department advances its capital necessitates the continual final reflux to it in the form of money, although this is once again brought about by the reconversion of the industrial capital into money-capital.’[Marx (1983a, 1885): vol. II, part III, chap. 20]
} 
value that the capitalist class realizes on the market under the form of the profit. Hence it is convenient to the capitalist class that the working class does not save at all.

The firms and the capitalist households purchase consumer goods and means of production from the firms. The purchases and sales of the firms and the capitalist households take place between the functional agents of capitalist class. Accordingly, the money that these functional agents put into circulation, either as final consumption expenditure or as intermediate consumption and investment, changes of hands without leaving the capitalist class.

The means of production are purchased both as intermediate consumption and investment. The sum of inter-industrial sales and purchases between the firms corresponding to the intermediate consumption cancel. Hence, in the aggregate the intermediate consumption does not determine the realization of the surplus value contained in the commodities.

The effective demand of the capitalist class as whole develops either under the form of the consumption expenditure of the capitalist households or the investment of the industrial capitalists or both. In the aggregate, it is only through the development of the effective demand of the capitalist class that the formation of money market prices such that the (partial or total) monetization of the surplus value takes place.

The consumption demand of the capitalist households and the firms allows for the formation of a money flow of value in the sphere of circulation equal to the effective demand of the capitalist class. At the same time, the money given out by the capitalist households as consumption expenditure and the firms as investment flows back ultimately to the firms. Hence the formation of the money prices in the sphere of circulation implies the realization of the moneyed surplus value under the form of the ex post profit of the firms allowing the latter to finance to larger o lesser degree the production process. The firms being the private property of the capitalist wealth-owners, it follows that the capitalist class as a whole earns a money income equal to its own aggregate/effective demand.

The capitalist class has first to spend money in order to earn a money income. It is the disposal on money which conditions and constraints the effective demand of the capitalist class, not the disposal of a moneyed income that only materializes under the form of a 
realized money profit in the sphere of circulation as a result of the development of the effective demand of the capitalist class. That is, the effective demand of the capitalist class is constraint by the latter's disposal on money, not by its moneyed income. Hence Kalecki's dictum: "The capitalists earn what they spend, and the workers spend what they earn."

This proposition conveys the substance of the monetary logic of the principle of effective demand. Marx was perfectly aware of this particular point, always within the framework of the theory of labour value:

"So far as the entire capitalist class is concerned, the proposition that it must itself throw into circulation the money required for the realisation of its surplus-value (correspondingly also for the circulation of its capital, constant and variable) not only fails to appear paradoxical, but stands forth as a necessary condition of the entire mechanism. For there are here only two classes: the working-class disposing only of its labour-power, and the capitalist class, which has a monopoly of the social means of production and money. It would rather be a paradox if the working-class were to advance in the first instance from its own resources the money required for the realisation of the surplus-value contained in the commodities. But the individual capitalist makes this advance only by acting as a buyer, expending money in the purchase of articles of consumption or advancing money in the purchase of elements of his productive capital, whether of labour-power or means of production. He never parts with his money unless he gets an equivalent for it. He advances money to the circulation only in the same way as he advances commodities to it. He acts in both instances as the initial point of their circulation.'[Marx (1983a, 1885): vol. II, part III, chap. 20]

In the long-run equilibrium the ex ante money value of the effective demand of the capitalist class is equal to the surplus value in terms of money created by the variable capital in the production process. Accordingly, the aggregate ex post profit is equal to the ex ante surplus value.

However, in the short run the effective demand of the capitalist class might be exceed or fall short of the surplus value created by labour. The mismatch of the ex ante effective demand and the ex ante supply labour value will give way to macro-dynamic disequilibrium/cumulative processes. Thus, the principle of effective demand conveys the possibility of a demand-led business cycle. ${ }^{18}$

\footnotetext{
${ }^{18}$ Marx analysis can be stated formally. Let $C$ be the consumption of the households, $I$ the investment of the firms, and $D$ the aggregate final demand such that $D=C+I$. Let $W$ be the variable capital equal to the sum total
} 


\section{Final remarks - Marx, Keynes and Kalecki}

Marx's main purpose in volume II of Capital was the full statement of the capitalistic process of circulation. In particular, in section III of volume II of Capital he set up the accounting dynamics of the process of circulation of capital between the functional classes and between the economic productive sectors in a two-class two-sector capitalistic economy in terms of the 'reproduction schemes'.

The critical reflection of the social circulation process of capital led him to several fundamental results, some of which can already be found in Quesnay's analysis: (i) the consumption expenditure and investment of the capitalist class is conditioned by the availability of money and not the money income of the previous period as suggested by classical political economy, nor the money income of the present period as suggested by neoclassical economists; (ii) the effective demand under the form of the end consumption of the households and the investment of the firms conveys the formation of a monetary income in the circulation process equal to money value of such expenditure, such that "the capitalist class earns what it spends and the working class spends what it earns"; (iii) the investment determines the money income that finances the savings of the economy, and not the other way around as suggested by classical-neoclassical authors; (iv) the money put into circulation in the goods market directly or indirectly by the capitalist class returns back to the latter hands (as long as there is no saving on behalf of the working class); (v) the principle of effective demand conveys the possibility of both a demand-led business cycle characterized by the alternation of phases of accumulation of capital and of all-comprising

of wages paid to the workers. It follows that the (gross) profits $Q$ realized by the firms is given by the equation $Q=C+I-W$. Let $\mathrm{Cw}$ be the consumption of the working households, and $\mathrm{Sw}$ the savings of the working households, such $W=C w+S w$; and let $\mathrm{Cq}$ be the consumption of the capitalist households. It follows that $Q=(C q+C w)+I-(C w+S w)$, Hence $Q=C q+I-S w$. Marx and the classical economists assume that (in the long-run equilibrium) $S w=0$, i.e. the workers spend what they earn. By the same token $Q=C q+I$, i.e. the capitalist class earns under the form of the profits of the firms what it spends under the form of consumption and investment. Let $P$ be the surplus value created by labour, and $Y^{s}$ the (supply-side) income of the economy such that $Y^{s}=W+P$. In the long-run equilibrium $C+I=P$, hence $Q=P$. However, in the short-run disequilibrium either $Q=>P$ or $Q<P$ are possible, giving way to the demand-led dynamics of the business cycle.

Mutatis mutandi, a similar analysis is carried out by Kalecki and Keynes without recourse to the labour theory of value. Both Kalecki and Keynes developed the foundations of a demand-led business cycle in a monetary production economy. See in particular Keynes $(1971,1930)$ and Kalecki (1990); also Riese (1986). 
economic recession/crises; and (vi) the capital-labour as a social relation is reproduced sistematically through the twofold process production and circulation/realization. ${ }^{19}$

Marx's main proposition on the theory of the circulation process of capital discussed in section 2 holds generally. The capitalist class has the command upon the general purchasing power. If spent, either under the form of capitalist consumption or investment or both, the money will return back to the capitalist class either as the profit of the industrial capitalists, the interest of the moneyed capitalists, and the rent of the landlords. In the capitalitic economy, as in Quesnay's agricultural kingdom, the capitalist class being the proprietor class earns what it spends. It does it in such manner that it advances the surplus value to itself under the form of its own effective demand. In turn, the working class spends what it earns.

Since the publication of volume II of Marx's Capital in 1885, orthodox marxists and nonmarxists in Germany and elsewhere, "post-Keynesians" in England and the United States, "Circuitists" in Italy and France, and "Monetary keynesians" in Germany have widely contributed to the development of the theory of the circulation process and the principle of effective demand in a monetary production economy. In particular, in the third decade of the twentieth century, liberal Keynes in England, and socialist Kalecki in Poland (and later in England), but also liberal Lautenbach in Germany, argued out the monetary logic of the principle of effective demand. This allowed to them to foundate the demand-side macroeconomics of capital accumulation, business cycle, mercantilism, imperialism, economic (under-)development, and involuntary unemployment.

\footnotetext{
${ }^{19}$ Marx states in book IV of the Grundrisse: "Finally, the result of the process of production and realization is, above all, the reproduction and new production of the relation of capital and labour itself, of capitalist and worker. This social relation, production relation, appears in fact as an even more important result of the process than its material results. And more particularly, within this process the worker produces himself as labour capacity, as well as the capital confronting him, while at the same time the capitalist produces himself as capital as well as the living labour capacity confronting him. Each reproduces itself, by reproducing its other, its negation. The capitalist produces labour as alien; labour produces the product as alien. The capitalist produces the worker, and the worker the capitalist etc.'[Marx 1983b, 1857-158]
} 
Kalecki always made explicit reference to his intellectual debt to Marx on this particular point in his essays on the Theory of the capitalist dynamic (1933-1971). In particular, he credited Marx for having developed the first analysis of the economic circuit and the principle of effective demand of a capitalistic economy. In turn, Keynes seems to have reached by himself at the principle of effective demand, which he considers to be an essential moment of a monetary production economy, in A Treatise on Money (1930) and thereafter in the General theory (1936). Keynes gives credit to Malthus as being the founder of such principle. of the need to found the principle of effective demand, whilst he mentions Marx en passant, together with Hogson and Mayor Douglas on this particular issue.

Kalecki, like Marx in volume II of Capital, carries on the functional-approach analysis of effective demand. Economic agents are strictly divided into capitalists earning a capital income and workers earning a labour income. By contrast, in Keynes's personal-approach analysis the income of an individual agent may include both a positive fraction of both capital income and of labour income. Notwithstanding this analytical difference, the theoretical reflection of these two authors reaffirms the fundamental results Marx arrived at on the monetary logic of the economic circuit and the principle of effective demand in volume II of Capital.

Keynes and Kalecki, like Marx before them, divide the aggregate demand into consumption and investment. For these authors, the general theory of effective demand is a central concept of a monetary production economy. Also, the fundamental distinction between consumption and investment and the formulation plays a central part in a theory of the macroeconomic dynamics of the monetary production economy. For the first time in the history of economic thought, Keynes and Kalecki formulated several aggregate functions of both consumption and investment as a heuristic device by means of which they intended to model the economic dynamics of demand and income of the capitalist economy. The heuristics of the aggregate demand functions allows to reflect in a simple manner both the monetary logic of the economic circuit and the demand decision of the economic agents, in particular, the fact that it is money, not income, which constitutes the budget constraint of the capitalist class. 
Unlike Marx, both Keynes and Kalecki state the principle of effective demand without recourse to the classical labour theory of value. As noted in the introduction, the monetary logic of the economic circuit does not imply the classical labour theory of value. Hence the analysis of the social process of circulation of capital can be carried out in terms of monetary prices (of production) without recourse to Marx's system of labour values. This is the case of Keynes's and Kalecki's foundation of a monetary theory of production in the 1920s and 1930s.

Keynes formulated a monetary theory of value and capital in chapter 16 of the General Theory (1936), and Kalecki explained the prices and profits by means of a monopolistic mark-up pricing theory in his essays on the Theory of the capitalist dynamic (1933-1971). Like in the case of Keynes and Kalecki, substantial differences on the theory of value, capital and money, and on the concept of equilibrium as well, permeate the different versions of post-Keynes-Kalecki heterodoxies of capitalism. ${ }^{20}$

The substantial differences on value and distribution of these two authors has conditioned the scientific status of post-Keynes-Kalecki economics, in particular of Anglo-American Post-Keynesianism, Italo-French Circuitism and German Monetary Keynesianism. The discussion of this particular issue, which involves a critical analysis of fundamental aspects of the economics of value and distribution, is beyond the scope of this paper. ${ }^{21}$

\footnotetext{
${ }^{20}$ Kalecki's explanation of the profit implies that under free competition the latter is equal to zero in the longrun equilibrium. By contrast, Keynes's theory of profit implies that under free competition the long-run equilibrium rate of profit (i.e. the marginal efficiency of capital) is equal to the equilibrium money rate of interest. See Kalecki (1974, 1956), chapters 2 and 3; and Keynes (1936), chapter 17; also Riese (1986).

${ }^{21}$ See Delaplace/ Nell (1996); also Riese (2001).
} 


\section{Appendix}

\subsection{Marx's input-output matrices of simple reproduction}

A century after the publication of the first edition of Quesnay's Tableau économique, Marx formulated in the Grundrisse for the first time in the history of economic thought the inputoutput matrix of a circular production economy containing five productive sectors: two raw material industries, one machinery industry, one workers's necessaries industry and one capitalists's consumption goods industry. Reordering and transposing Marx's columns yields the modern input-output simple reproduction matrix shown below: ${ }^{22}$

\section{Input-output matrix I}

\begin{tabular}{|l|c|c|c|c|c|c|c|c|}
\hline $\begin{array}{l}\text { Values flows in } \\
\text { terms of sterling } \\
\text { pounds }\end{array}$ & $\begin{array}{c}\text { Raw } \\
\text { materials } \\
\text { industry 1) }\end{array}$ & $\begin{array}{c}\text { Raw } \\
\text { materials } \\
\text { industry 2 }\end{array}$ & $\begin{array}{c}\text { Machinery } \\
\text { industry }\end{array}$ & $\begin{array}{c}\text { Worker's } \\
\text { necessaries } \\
\text { industry }\end{array}$ & $\begin{array}{c}\text { Capitalists's } \\
\text { consumtption } \\
\text { goods } \\
\text { industry } \\
(2)\end{array}$ & $\begin{array}{c}\text { Worker's } \\
\text { consumption }\end{array}$ & $\begin{array}{c}\text { Capitalist's } \\
\text { consumption }\end{array}$ & $\begin{array}{c}\text { Total } \\
\text { demand }\end{array}$ \\
\hline $\begin{array}{l}\text { Raw materials } \\
(1 \text { and 2) }\end{array}$ & 40 & 40 & 40 & 40 & 40 & & $(7)$ & $(8)$ \\
\hline Maschinery & 20 & 20 & 20 & 20 & 20 & & 100 & 100 \\
\hline Wages & 20 & 20 & 20 & 20 & 20 & & 100 \\
\hline $\begin{array}{l}\text { Capitalists's } \\
\text { surplus value }\end{array}$ & 20 & 20 & 20 & 20 & 20 & & 100 \\
\hline Total supply & 100 & 100 & 100 & 100 & 100 & & & 100 \\
\hline
\end{tabular}

Marx's Tableau shows a long-run self-replacement state equilibrium of interdependent industries of a capitalist economy. Though Marx also considers en passant the consequences of a reduction of the capitalists's consumption, the possibility of a demand-

\footnotetext{
${ }^{22}$ Columns (7) and (8) containing the consumption demand of the workers and the capitalists, and column (9) containing the total demand are not formulated by Marx. However, they can be obtained directly from the context from which the matrix has been taken. See Marx (mew 42, Heft IV): 355.
} 
led crises, and the dynamics of capital accumulation and technical (productivity) change. However, he does not offer a thorough theoretical explanation of the sparking moment of these processes.

Marx also formulates in section III of volume II of Capital several numerical examples of for both simple and extended reproduction by means of the reproduction schemes. ${ }^{23}$ In chapter 20 of volume II on "Simple reproduction" he first discusses a two sector economy with the first department producing means of production (Sraffa's basic commodities) by means of circularly produced capital goods labour, and the second department producing consumption goods (Sraffa's non-basic commodities) produced by means of circularly produced capital goods and labour. This yields the input-output matrix shown below:

\section{Input-output matrix II}

\begin{tabular}{|l|c|c|c|c|}
\hline $\begin{array}{l}\text { Flow values in sterling } \\
\text { pounds }\end{array}$ & Department I & Department II & Consumption & $\begin{array}{c}\text { Total } \\
\text { demand }\end{array}$ \\
\hline Means of production & 4000 & 2000 & 0 & 6000 \\
\hline Consumption goods & 0 & 0 & 3000 & 3000 \\
\hline Wages & 1000 & 500 & & \\
\hline Surplus value & 1000 & 500 & & \\
\hline New value-added & 2000 & 1000 & 3000 & \\
\hline Total supply & 6000 & 3000 & & 9000 \\
\hline
\end{tabular}

Next Marx modifies the basic input-output matrix such that the department II is divided into a necessaries industry (department IIa) and a luxury industry (department IIb). The necessaries are consumed by both the workers and the capitalists, while the luxury goods are only consumed by the capitalists. It is assumed that the capitalists spend $3 / 5$ of their

\footnotetext{
${ }^{23}$ Samuelson (1977) suggests that the fact that Marx worked out the simple reproduction case in the $1860 \mathrm{~s}$ and the extended reproduction case in the 1870s might explain why Marx did not use to his original simple reproduction example to develop the extended reproduction case in volume II of Capital.
} 
income to buy necessaries and $2 / 5$ to buy luxury goods. This yields the following inputoutput matrix III:

\section{Input-output matrix III}

\begin{tabular}{|l|c|c|c|c|c|c|c|}
\hline $\begin{array}{l}\text { Flow values } \\
\text { in sterling } \\
\text { pounds }\end{array}$ & Dept. I & Dept. IIa & Dept. IIb & $\begin{array}{c}\text { Workers's } \\
\text { consumption }\end{array}$ & $\begin{array}{c}\text { Capitalist's } \\
\text { consumption }\end{array}$ & $\begin{array}{c}\text { End } \\
\text { consumtion }\end{array}$ & $\begin{array}{c}\text { Total } \\
\text { demand }\end{array}$ \\
\hline $\begin{array}{l}\text { Means of } \\
\text { production }\end{array}$ & 4000 & 1600 & 400 & & & & 6000 \\
\hline Neccesaries & 0 & 0 & 0 & 1500 & 900 & 2400 & 2400 \\
\hline Luxury goods & 0 & 0 & 0 & & 600 & 600 & 600 \\
\hline Wages & 1000 & 400 & 100 & 1500 & & & \\
\hline $\begin{array}{l}\text { Capital (incl. } \\
\text { Wages) }\end{array}$ & 5000 & 2000 & 500 & & & & \\
\hline Surplus value & 1000 & 400 & 100 & & 1500 & & \\
\hline $\begin{array}{l}\text { New value- } \\
\text { added }\end{array}$ & 2000 & 800 & 200 & & & & \\
\hline Total supply & 6000 & 2400 & 600 & & & & \\
\hline
\end{tabular}

Marx worked out fragmentarily a second modification of the basic input-output matrix in order to show how the fixed capital in the consumption industry (department II) is replaced during the yearly process of circulation of the simple reproduction case. All individual capitalists depreciate every year their fixed capital. However, not all capitalists replace their fixed capital every year. Hence, the individual capitals of department II is divided in two parts, e.g. part II.2 replaces its fixed capital during the given year, not so part II.1. In totto in the self-replacement state the gross investment of department II is equal to the depreciation of fixed capital, i.e. 10\% of constant capital in this department. It is assumed that part II.1. and part II.2 are of equal size in terms of constant capital, variable capital and surplus value. Although not considered by Marx, the depreciation of fixed capital in department $\mathrm{I}$ is assumed to be equal to 400 sterling pounds, i.e. $10 \%$ of constant capital, as in department II. Under these assumptions, Marx's complete numerical example yields the input-output matrix IV shown below. 


\section{Input-output matrix IV}

\begin{tabular}{|l|c|c|c|c|c|c|c|c|c|c|c|c|}
\hline $\begin{array}{l}\text { Flow values } \\
\text { in sterling } \\
\text { pounds }\end{array}$ & Dept. I & $\begin{array}{c}\text { Dept. } \\
\text { II.1 }\end{array}$ & $\begin{array}{c}\text { Dept. } \\
\text { II.2 }\end{array}$ & $\begin{array}{c}\text { Work's } \\
\text { consum. }\end{array}$ & $\begin{array}{c}\text { Capit's } \\
\text { consum. }\end{array}$ & $\begin{array}{c}\text { End } \\
\text { consum. }\end{array}$ & $\begin{array}{c}\text { Gross } \\
\text { invest. } \\
\text { I }\end{array}$ & $\begin{array}{c}\text { Gross } \\
\text { invest. } \\
\text { II.1 }\end{array}$ & $\begin{array}{c}\text { Gross } \\
\text { invest. } \\
\text { II.2 }\end{array}$ & $\begin{array}{c}\text { Gross } \\
\text { invest. }\end{array}$ & $\begin{array}{c}\text { End } \\
\text { demand }\end{array}$ & $\begin{array}{c}\text { Total } \\
\text { demand }\end{array}$ \\
\hline $\begin{array}{l}\text { Means of } \\
\text { production }\end{array}$ & 3600 & 900 & 900 & & & & 400 & 0 & 200 & 600 & 600 & 6000 \\
\hline Necessaries & 0 & 0 & 0 & 750 & 750 & & & & & & 1500 & 1500 \\
\hline $\begin{array}{l}\text { Luxury } \\
\text { goods }\end{array}$ & 0 & 0 & 0 & 750 & 750 & & & & & & 1500 & 1500 \\
\hline Wages & 1000 & 250 & 250 & 1500 & & & & & & & & \\
\hline $\begin{array}{l}\text { Capital } \\
\text { (incl. wages) }\end{array}$ & 5000 & 1250 & 1250 & & & & & & & & & \\
\hline $\begin{array}{l}\text { Surplus } \\
\text { value }\end{array}$ & 1000 & 250 & 250 & & 1500 & & & & & & & \\
\hline $\begin{array}{l}\text { New value- } \\
\text { added }\end{array}$ & 2000 & 500 & 500 & & & 3000 & & & & & & \\
\hline Depreciation & 400 & 100 & 100 & & & & & & & 200 & & \\
\hline $\begin{array}{l}\text { Gross } \\
\text { income }\end{array}$ & 2400 & 600 & 600 & & & & & & & & & \\
\hline Total supply & 6000 & 1500 & 1500 & & & & & & & & & 9000 \\
\hline
\end{tabular}

4.2. The accounting dynamics of simple reproduction of a capitalistic economy

This section contains the accounting dynamics of the processes of production and circulation of the simple reproduction economy described by input-ouput matrix III in section 4.1. This is done by means of a system of credit-debit tables currently used by German authors. The tables describe the position of each agent at each stage. Changes between stages of both the circulation process and the production process are shown in bold letters.

The main advantages of this way of registering the transactions carried out by the functional agents in different economic sectors are that: (i) it provides a systematic overview of what is going on in the economy at the individual, sectoral and aggregate level, and (ii) it allows to keep record of the all transactions during the economic process. The 
description of the circulation process follows as close as possible Marx's discussion in chapter 20 of volume II of Capital [Marx (1983a, vol. II, chap. 20): 398-420]

The economy is divided in two departments. Department I produces means of production by means of capital goods and labour, and department II produces consumption goods by means of capital goods and labour. No distinction between fixed and circulating capital is considered. Department II is divided in two subdepartments. Department IIa produces necessaries; and department IIb produces luxury commodities.

The economy contains two main functional economic classes, i.e. the capitalist class and the working class. The capitalist class splits functionally into the firms, the wealth-owners and the capitalist households. This particularization of the capitalist class goes beyond Marx's own analysis, however, it does not stand in contradiction neither with his central assumptions nor with his analysis nor with his main results. The working class splits functionally into wage workers and working households.

The wage workers are paid the money wage by the firms at the end of the production process, and they transfer all their income to the working households. On their turn the working households spend the money against consumption goods produced in department IIa. The firms pay the money capital income (equal to the surplus value) to the capitalist wealth-owners. On their turn the capitalist wealth-owners transfer their income to the capitalist households, and the latter spend all the money against necessaries (of better quality than those consumed by the working households) produced in department IIa and luxury goods (not affordable by the working households) produced in department IIb.

It then becomes apparent that the consumption expenditure of the capitalist households allows for the formation of a money value during the circulation process equal to the capital income of the wealth-owners. In this way the money spent by the capitalist households returns to the firms under the form of the latters's gross profit. This allows the firms to finance the capitalist process of production. The completion of the circulation process allows for both the recreation of the capital-labour relation and the recreation of the material and financial conditions of the process of production and valorization of capital. 
The notation runs as follows: $M-$ money, $M p$ - means of production, $\mathrm{Sg}$ - subsistence goods/necessaries, Lg - luxury goods, $Q$ - surplus value or gross profit, $W$ - wages, $C-$ consumption, $V A$ - value added. The numbers of value flows are given in sterling pounds. 


\subsubsection{The circulation process}

(1) The position of each class at the end of the production process, and before the beginnning of the circulation process is described by the system of tables. The money in the economy is distributed amongst the firms.

\begin{tabular}{ll|ll}
\multicolumn{4}{c}{ I. Means of production } \\
\hline \multicolumn{4}{c}{ Firms I } \\
\hline$M$ & 1000 & $M$ & 1000 \\
$M \boldsymbol{p}$ & $\mathbf{6 0 0 0}$ & $M p_{1}$ & 4000 \\
& & $Q_{1}$ & 1000 \\
& & $W_{1}$ & 1000
\end{tabular}

\begin{tabular}{cr|lr}
\multicolumn{4}{c}{ IIa. Subsistence goods (necessaries) } \\
\hline \multicolumn{4}{c}{ Firms IIa } \\
\hline$M$ & 300 & $M$ & 300 \\
Sg & 2400 & $M p_{2 a}$ & 1600 \\
& & $Q_{2 a}$ & 400 \\
& & $W_{2 a}$ & 400
\end{tabular}

\begin{tabular}{ll|ll}
\multicolumn{3}{c}{ IIb. Luxury goods } \\
\hline \multicolumn{4}{c}{ Firms IIb } \\
\hline$M$ & 200 & $M$ & 200 \\
$\boldsymbol{L g}$ & $\mathbf{6 0 0}$ & $M p_{2 b}$ & 400 \\
& & $Q_{2 b}$ & 100 \\
& & $W_{2 b}$ & 100
\end{tabular}
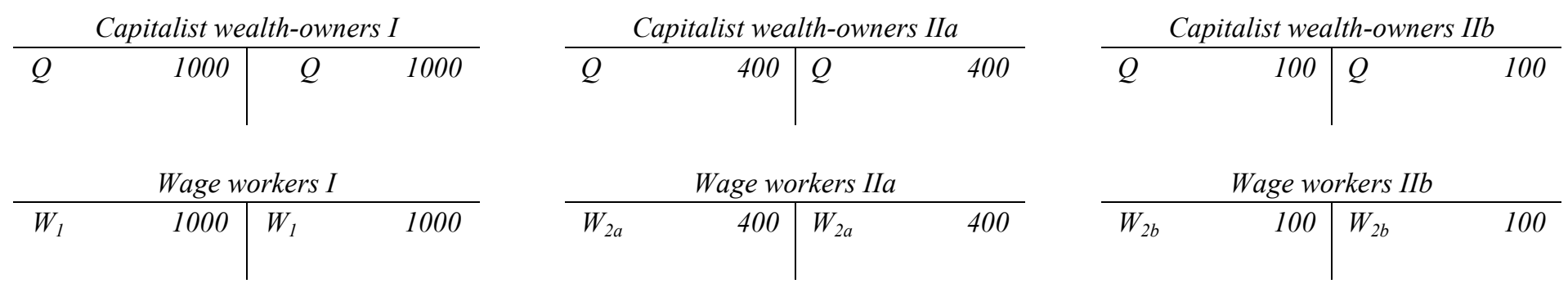

\begin{tabular}{rr|ll}
\multicolumn{4}{c}{ Capitalist Households I } \\
\hline$Q$ & 1000 & $C$ & 1000 \\
& Working Households I \\
\hline W & 1000 & C & 1000
\end{tabular}

\begin{tabular}{rr|l|l}
\multicolumn{4}{c}{ Capitalist Households IIa } \\
\hline$Q$ & 400 & C & 400 \\
& & & \\
\multicolumn{4}{|c}{ Working Households IIa } \\
\hline$W$ & 400 & C & 400
\end{tabular}

\begin{tabular}{rr|l|l}
\multicolumn{4}{c}{ Capitalist Households IIb } \\
\hline W & & & \\
& & & \\
\multicolumn{4}{c}{ Working Households IIb } \\
\hline$W$ & 100 & $C$ & 100
\end{tabular}


(2) Firms I pay the wages for $£ 1000$ to the workers. End of wage contract of workers I. The workers are fired and the new unemployed ex-wage workers go back to the "reserve army of the unvoluntarily unemployed".

\begin{tabular}{cr|lr}
\multicolumn{4}{c}{ I. Means of production } \\
\hline \multicolumn{4}{c}{ Firms I } \\
\hline $\boldsymbol{M}$ & $\boldsymbol{0}$ & $M$ & 1000 \\
$M p$ & 6000 & $M p_{1}$ & 4000 \\
& & $Q_{1}$ & 1000 \\
& & $\boldsymbol{W}_{\boldsymbol{1}}$ & $\mathbf{0}$
\end{tabular}

\begin{tabular}{cr|lr}
\multicolumn{4}{c}{ IIa. Subsistence goods (necessaries) } \\
\hline \multicolumn{4}{c}{ Firms IIa } \\
\hline$M$ & 300 & $M$ & 300 \\
$S g$ & 2400 & $M p_{2 a}$ & 1600 \\
& & $Q_{2 a}$ & 400 \\
& & $W_{2 a}$ & 400
\end{tabular}

\begin{tabular}{ll|ll}
\multicolumn{3}{c}{ IIb. Luxury goods } \\
\hline \multicolumn{4}{c}{ Firms IIb } \\
\hline$M$ & 200 & $M$ & 200 \\
$L g$ & 600 & $M p_{2 b}$ & 400 \\
& & $Q_{2 b}$ & 100 \\
& & $W_{2 b}$ & 100
\end{tabular}
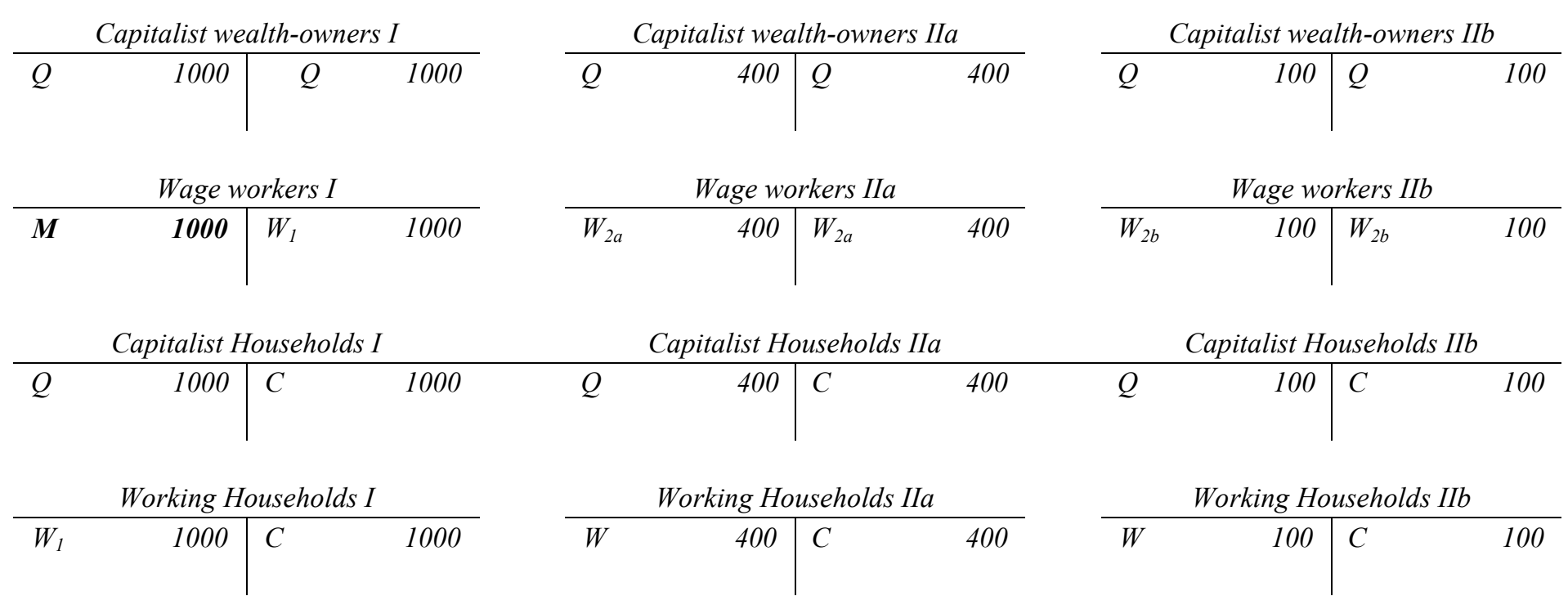

\begin{tabular}{cc|ll}
\multicolumn{4}{c}{ Capitalist Households IIa } \\
\hline Q & 400 & C & 400 \\
& & & \\
\multicolumn{4}{c}{ Working Households IIa } \\
\hline$W$ & 400 & $C$ & 400
\end{tabular}

\begin{tabular}{rr|ll}
\multicolumn{4}{c}{ Capitalist Households IIb } \\
\hline$\quad 100$ & C & 100
\end{tabular}

\begin{tabular}{cc|cc}
\multicolumn{4}{c}{ Working Households IIb } \\
\hline W 100 & C & 100
\end{tabular}


(3) Workers I transfer $£ 1000$ to the working households I.

\begin{tabular}{cr|lr}
\multicolumn{4}{c}{ I. Means of production } \\
\hline \multicolumn{4}{c}{ Firms I } \\
\hline$M$ & 0 & $M$ & 1000 \\
$M p$ & 6000 & $M p_{1}$ & 4000 \\
& & $Q_{1}$ & 1000 \\
& & $W_{1}$ & 0
\end{tabular}

\begin{tabular}{cr|lr}
\multicolumn{4}{c}{ IIa. Subsistence goods (necessaries) } \\
\hline \multicolumn{4}{c}{ Firms IIa } \\
\hline$M$ & 300 & $M$ & 300 \\
$S g$ & 2400 & $M p_{2 a}$ & 1600 \\
& & $Q_{2 a}$ & 400 \\
& & $W_{2 a}$ & 400
\end{tabular}

\begin{tabular}{ll|ll}
\multicolumn{3}{c}{ IIb. Luxury goods } \\
\hline \multicolumn{4}{c}{ Firms IIb } \\
\hline$M$ & 200 & $M$ & 200 \\
$L g$ & 600 & $M p_{2 b}$ & 400 \\
& & $Q_{2 b}$ & 100 \\
& & $W_{2 b}$ & 100
\end{tabular}

\begin{tabular}{lr|cc}
\multicolumn{4}{c}{ Capitalist wealth-owners I } \\
\hline Q & 1000 & $Q$ & 1000
\end{tabular}
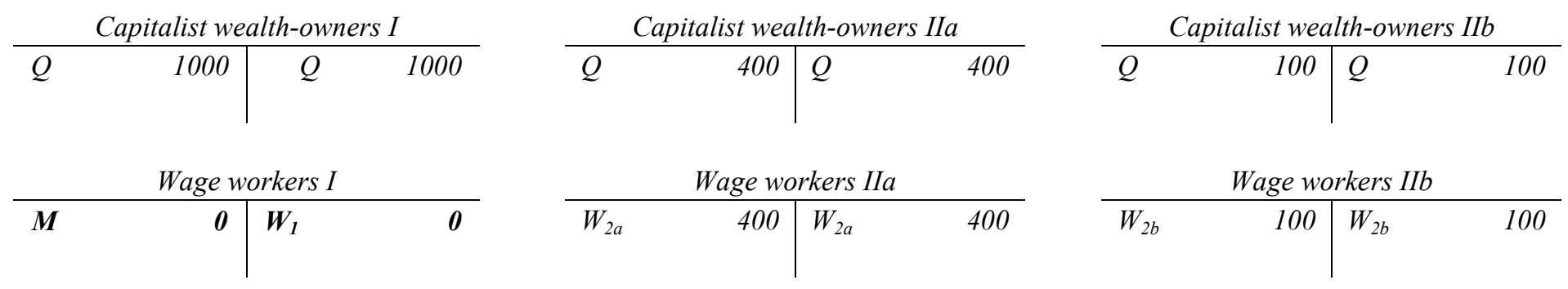

\begin{tabular}{lr|ll}
\multicolumn{4}{c}{ Capitalist Households I } \\
\hline$Q$ & 1000 & $C$ & 1000 \\
& & & \\
\multicolumn{4}{c}{ Working Households I } \\
\hline M & $\mathbf{1 0 0 0}$ & C & 1000
\end{tabular}

\begin{tabular}{cr|ll}
\multicolumn{4}{c}{ Capitalist Households IIa } \\
\hline$Q$ & 400 & $C$ & 400 \\
& Working Households IIa \\
\hline \multicolumn{4}{c}{} \\
\hline$W$ & 400 & $C$ & 400
\end{tabular}

\begin{tabular}{rr|ll}
\multicolumn{4}{c}{ Capitalist Households IIb } \\
\hline W & 100 & C & 100 \\
& & & \\
\multicolumn{4}{c}{ Working Households IIb } \\
\hline$W$ & 100 & C & 100
\end{tabular}


(4) Working households I buy subsistence goods for $£ 1000$ from firms IIa. End of circulation process of workers I.

\begin{tabular}{cr|lr}
\multicolumn{4}{c}{ I. Means of production } \\
\hline \multicolumn{4}{c}{ Firms I } \\
\hline$M$ & 0 & $M$ & 1000 \\
$M p$ & 6000 & $M p_{1}$ & 4000 \\
& & $Q_{1}$ & 1000 \\
& & $W_{1}$ & 0
\end{tabular}

\begin{tabular}{cc|lr}
\multicolumn{4}{c}{ IIa. Subsistence goods (necessaries) } \\
\hline \multicolumn{4}{c}{ Firms IIa } \\
\hline $\boldsymbol{M}$ & $\mathbf{1 3 0 0}$ & $M$ & 300 \\
$\boldsymbol{S g}$ & $\mathbb{1 4 0 0}$ & $M p_{2 a}$ & 1600 \\
& & $Q_{2 a}$ & 400 \\
& & $W_{2 a}$ & 400
\end{tabular}

\begin{tabular}{ll|ll}
\multicolumn{3}{c}{ IIb. Luxury goods } \\
\hline \multicolumn{4}{c}{ Firms IIb } \\
\hline$M$ & 200 & $M$ & 200 \\
$L g$ & 600 & $M p_{2 b}$ & 400 \\
& & $Q_{2 b}$ & 100 \\
& & $W_{2 b}$ & 100
\end{tabular}

\begin{tabular}{lr|cc}
\multicolumn{4}{c}{ Capitalist wealth-owners I } \\
\hline Q & 1000 & $Q$ & 1000
\end{tabular}
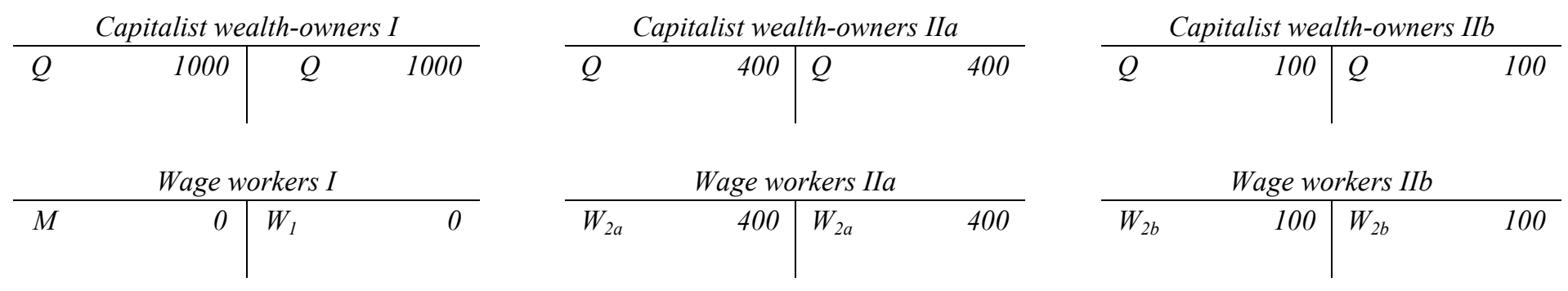

\begin{tabular}{lr|ll}
\multicolumn{4}{c}{ Capitalist Households I } \\
\hline$Q$ & 1000 & $C$ & 1000 \\
& & & \\
\multicolumn{4}{c}{ Working Households I } \\
\hline Sg & $\mathbf{1 0 0 0}$ & C & 1000
\end{tabular}

\begin{tabular}{cr|ll}
\multicolumn{4}{c}{ Capitalist Households IIa } \\
\hline$Q$ & 400 & $C$ & 400 \\
& Working Households IIa \\
\hline \multicolumn{4}{c}{} \\
\hline$W$ & 400 & $C$ & 400
\end{tabular}

\begin{tabular}{rr|ll}
\multicolumn{4}{c}{ Capitalist Households IIb } \\
\hline W & 100 & C & 100 \\
& & & \\
\multicolumn{4}{c}{ Working Households IIb } \\
\hline$W$ & 100 & C & 100
\end{tabular}


(5) Firms IIa buy means of production for $£ 1000$ from firms I.

\begin{tabular}{lr|lr}
\multicolumn{4}{c}{ I. Means of production } \\
\hline \multicolumn{4}{c}{ Firms I } \\
\hline $\boldsymbol{M}$ & $\mathbf{1 0 0 0}$ & $M$ & 1000 \\
$\boldsymbol{M p}$ & $\mathbf{5 0 0 0}$ & $M p_{1}$ & 4000 \\
& & $Q_{1}$ & 1000 \\
& & $W_{1}$ & 0
\end{tabular}

\begin{tabular}{cr|lr}
\multicolumn{4}{c}{ IIa. Subsistence goods (necessaries) } \\
\hline \multicolumn{4}{c}{ Firms IIa } \\
\hline $\boldsymbol{M}$ & $\mathbf{3 0 0}$ & $M$ & 300 \\
Sg & 1400 & $M p_{2 a}$ & 1600 \\
$\boldsymbol{M p}$ & $\mathbf{1 0 0 0}$ & $Q_{2 a}$ & 400 \\
& & $W_{2 a}$ & 400
\end{tabular}

\begin{tabular}{ll|ll}
\multicolumn{3}{c}{ IIb. Luxury goods } \\
\hline \multicolumn{4}{c}{ Firms IIb } \\
\hline$M$ & 200 & $M$ & 200 \\
$L g$ & 600 & $M p_{2 b}$ & 400 \\
& & $Q_{2 b}$ & 100 \\
& & $W_{2 b}$ & 100
\end{tabular}
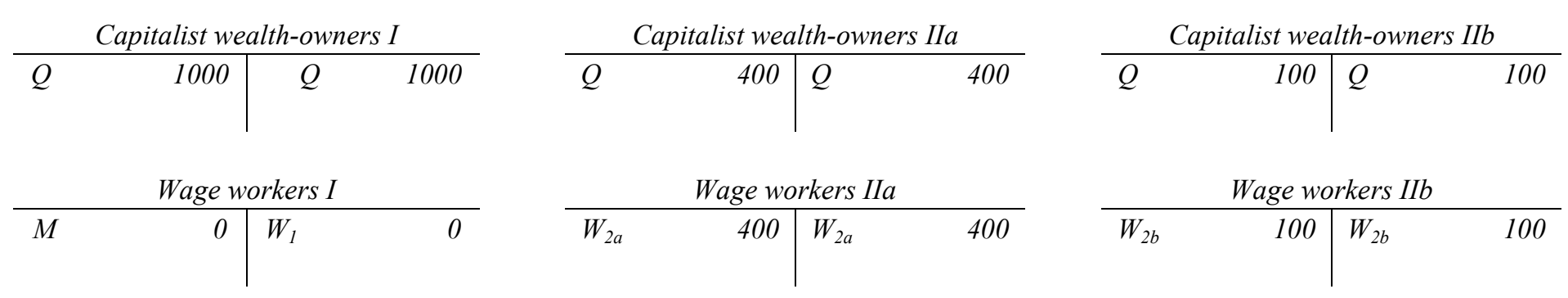

\begin{tabular}{cr|ll}
\multicolumn{4}{c}{ Capitalist Households I } \\
\hline$Q$ & 1000 & $C$ & 1000 \\
& & & \\
\multicolumn{4}{c}{ Working Households I } \\
\hline$S g$ & 1000 & $C$ & 1000
\end{tabular}

\begin{tabular}{cr|ll}
\multicolumn{4}{c}{ Capitalist Households IIa } \\
\hline$Q$ & 400 & $C$ & 400 \\
& Working Households IIa \\
\hline \multicolumn{4}{c}{} \\
\hline$W$ & 400 & $C$ & 400
\end{tabular}

\begin{tabular}{|c|c|c|c|}
\hline \multicolumn{4}{|c|}{ Capitalist Households IIb } \\
\hline$Q$ & 100 & $C$ & 100 \\
\hline \multicolumn{4}{|c|}{ Working Households IIb } \\
\hline$W$ & 100 & $C$ & 100 \\
\hline
\end{tabular}


(6) Firms IIa buy means of production for $£ 300$ from firms I. And firms IIb buy means of production for $£ 200$ from firms I.

\begin{tabular}{lr|lr}
\multicolumn{4}{c}{ I. Means of production } \\
\hline \multicolumn{4}{c}{ Firms I } \\
\hline $\boldsymbol{M}$ & $\mathbf{1 5 0 0}$ & $M$ & 1000 \\
$\boldsymbol{M p}$ & 4500 & $M p_{1}$ & 4000 \\
& & $Q_{1}$ & 1000 \\
& & $W_{1}$ & 0
\end{tabular}

\begin{tabular}{lr|lr}
\multicolumn{4}{c}{ IIa. Subsistence goods (necessaries) } \\
\hline \multicolumn{4}{c}{ Firms IIa } \\
\hline $\boldsymbol{M}$ & $\boldsymbol{0}$ & $M$ & 300 \\
$S g$ & 1400 & $M p_{2 a}$ & 1600 \\
$\boldsymbol{M p}$ & 1300 & $Q_{2 a}$ & 400 \\
& & $W_{2 a}$ & 400
\end{tabular}

\begin{tabular}{lr|lr}
\multicolumn{4}{c}{ IIb. Luxury goods } \\
\hline \multicolumn{4}{c}{ Firms IIb } \\
\hline $\boldsymbol{M}$ & $\boldsymbol{0}$ & $M$ & 200 \\
$L g$ & 600 & $M p_{2 b}$ & 400 \\
$\boldsymbol{M p}$ & 200 & $Q_{2 b}$ & 100 \\
& & $W_{2 b}$ & 100
\end{tabular}

\begin{tabular}{ll|ll}
\multicolumn{4}{c}{ Capitalist wealth-owners I } \\
\hline Q & 1000 & $Q$ & 1000
\end{tabular}
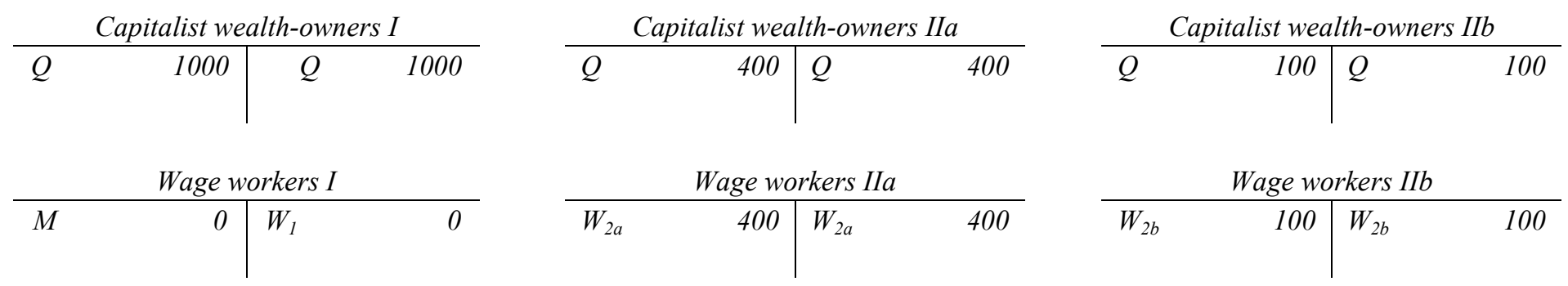

\begin{tabular}{cr|ll}
\multicolumn{4}{c}{ Capitalist Households I } \\
\hline$Q$ & 1000 & $C$ & 1000 \\
& & & \\
\multicolumn{4}{c}{ Working Households I } \\
\hline$S g$ & 1000 & $C$ & 1000
\end{tabular}

\begin{tabular}{|c|c|c|c|}
\hline \multicolumn{4}{|c|}{ Capitalist Households IIa } \\
\hline$Q$ & 400 & $C$ & 400 \\
\hline \multicolumn{4}{|c|}{ Working Households IIa } \\
\hline$W$ & 400 & $C$ & 400 \\
\hline
\end{tabular}

\begin{tabular}{rr|ll}
\multicolumn{4}{c}{ Capitalist Households IIb } \\
\hline W & 100 & C & 100 \\
& & & \\
\multicolumn{4}{c}{ Working Households IIb } \\
\hline$W$ & 100 & C & 100
\end{tabular}


(7) Firms I transfer the capital income for $£ 500$ to the wealth-owners I before having having moneyed their profit.

\begin{tabular}{cr|lr}
\multicolumn{4}{c}{ I. Means of production } \\
\hline \multicolumn{4}{c}{ Firms I } \\
\hline$M$ & $\mathbf{1 0 0 0}$ & $M$ & 1000 \\
$M p$ & 4500 & $M p_{1}$ & 4000 \\
& & $Q_{l}$ & 500 \\
& & $W_{1}$ & 0
\end{tabular}

\begin{tabular}{lr|lr}
\multicolumn{4}{c}{ IIa. Subsistence goods (necessaries) } \\
\hline \multicolumn{4}{c}{ Firms IIa } \\
\hline $\boldsymbol{M}$ & $\boldsymbol{0}$ & $M$ & 300 \\
$\mathrm{Sg}$ & 1400 & $M p_{2 a}$ & 1600 \\
$\boldsymbol{M p}$ & $\mathbf{1 3 0 0}$ & $Q_{2 a}$ & 400 \\
& & $W_{2 a}$ & 400
\end{tabular}

\begin{tabular}{lr|lr}
\multicolumn{4}{c}{ IIb. Luxury goods } \\
\hline \multicolumn{4}{c}{ Firms IIb } \\
\hline $\boldsymbol{M}$ & $\boldsymbol{0}$ & $M$ & 200 \\
$\mathrm{Lg}$ & 600 & $M p_{2 b}$ & 400 \\
$\boldsymbol{M p}$ & 200 & $Q_{2 b}$ & 100 \\
& & $W_{2 b}$ & 100
\end{tabular}
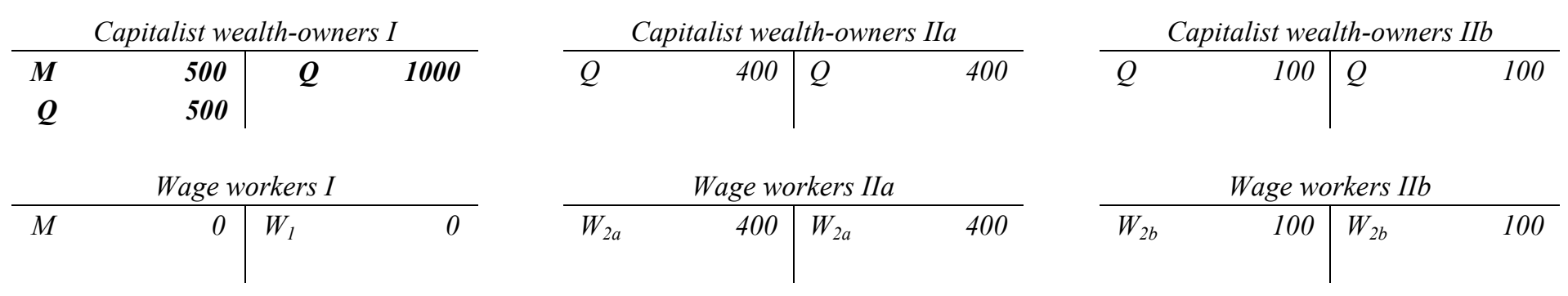

\begin{tabular}{cr|ll}
\multicolumn{4}{c}{ Capitalist Households I } \\
\hline$Q$ & 1000 & $C$ & 1000 \\
& & & \\
\multicolumn{4}{c}{ Working Households I } \\
\hline$S g$ & 1000 & $C$ & 1000
\end{tabular}

\begin{tabular}{|c|c|c|c|}
\hline \multicolumn{4}{|c|}{ Capitalist Households IIa } \\
\hline$Q$ & 400 & $C$ & 400 \\
\hline \multicolumn{4}{|c|}{ Working Households IIa } \\
\hline$W$ & 400 & $C$ & 400 \\
\hline
\end{tabular}

\begin{tabular}{|c|c|c|c|}
\hline \multicolumn{4}{|c|}{ Capitalist Households IIb } \\
\hline$Q$ & 100 & $C$ & 100 \\
\hline \multicolumn{4}{|c|}{ Working Households IIb } \\
\hline$W$ & 100 & $C$ & 100 \\
\hline
\end{tabular}


(8) Wealth-owners I transfer $£ 500$ to the capitalist households I

\begin{tabular}{cr|lr}
\multicolumn{4}{c}{ I. Means of production } \\
\hline \multicolumn{4}{c}{ Firms I } \\
\hline$M$ & $\mathbf{1 0 0 0}$ & $M$ & 1000 \\
$M p$ & 4500 & $M p_{1}$ & 4000 \\
& & $Q_{1}$ & 500 \\
& & $W_{1}$ & 0
\end{tabular}

\begin{tabular}{lr|lr}
\multicolumn{4}{c}{ IIa. Subsistence goods (necessaries) } \\
\hline \multicolumn{4}{c}{ Firms IIa } \\
\hline $\boldsymbol{M}$ & $\boldsymbol{0}$ & $M$ & 300 \\
$S g$ & 1400 & $M p_{2 a}$ & 1600 \\
$\boldsymbol{M p}$ & 1300 & $Q_{2 a}$ & 400 \\
& & $W_{2 a}$ & 400
\end{tabular}

\begin{tabular}{lr|lr}
\multicolumn{4}{c}{ IIb. Luxury goods } \\
\hline \multicolumn{4}{c}{ Firms IIb } \\
\hline $\boldsymbol{M}$ & $\boldsymbol{0}$ & $M$ & 200 \\
$L g$ & 600 & $M p_{2 b}$ & 400 \\
$\boldsymbol{M p}$ & 200 & $Q_{2 b}$ & 100 \\
& & $W_{2 b}$ & 100
\end{tabular}
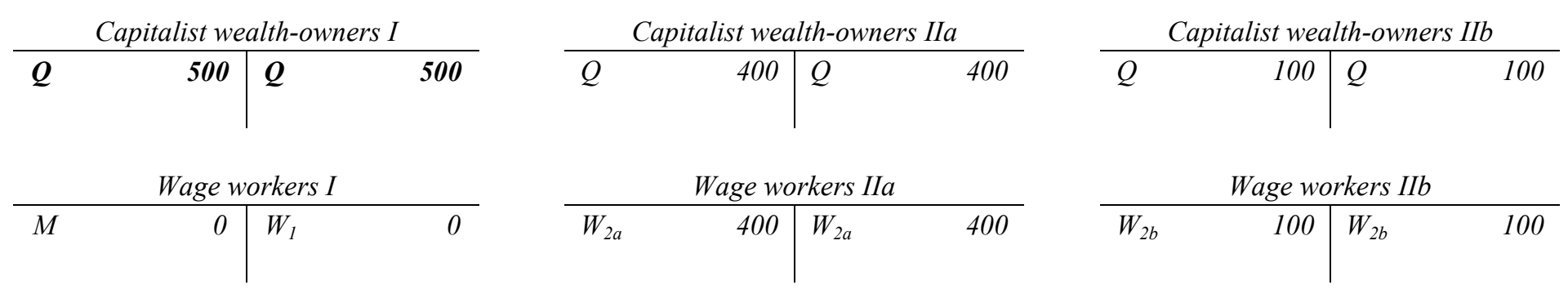

\begin{tabular}{cr|ll}
\multicolumn{4}{c}{ Capitalist Households I } \\
\hline $\boldsymbol{M}$ & $\mathbf{5 0 0}$ & $\mathrm{C}$ & 1000 \\
$\boldsymbol{Q}$ & $\mathbf{5 0 0}$ & & \\
\multicolumn{4}{c}{ Working Households I } \\
\hline $\mathrm{Sg}$ & 1000 & $\mathrm{C}$ & 1000
\end{tabular}

\begin{tabular}{cr|ll}
\multicolumn{4}{c}{ Capitalist Households IIa } \\
\hline$Q$ & 400 & $C$ & 400 \\
& Working Households IIa \\
\hline \multicolumn{4}{c}{} \\
\hline$W$ & 400 & $C$ & 400
\end{tabular}

\begin{tabular}{rr|ll}
\multicolumn{4}{c}{ Capitalist Households IIb } \\
\hline W & 100 & C & 100 \\
& & & \\
\multicolumn{4}{c}{ Working Households IIb } \\
\hline$W$ & 100 & C & 100
\end{tabular}


(9) Capitalist households I spend $£ 300$ to buy necessaries from firms IIa; they also spend $£ 200$ to buy luxury goods from firms IIb.

\begin{tabular}{cr|lr}
\multicolumn{4}{c}{ I. Means of production } \\
\hline \multicolumn{4}{c}{ Firms I } \\
\hline$M$ & $\mathbf{1 0 0 0}$ & $M$ & 1000 \\
$M p$ & 4500 & $M p_{1}$ & 4000 \\
& & $Q_{l}$ & 500 \\
& & $W_{1}$ & 0
\end{tabular}

\begin{tabular}{lr|lr}
\multicolumn{4}{c}{ IIa. Subsistence goods (necessaries) } \\
\hline \multicolumn{4}{c}{ Firms IIa } \\
\hline $\boldsymbol{M}$ & $\mathbf{3 0 0}$ & $M$ & 300 \\
$\mathbf{S g}$ & $\mathbf{1 1 0 0}$ & $M p_{2 a}$ & 1600 \\
$\mathrm{Mp}$ & 1300 & $Q_{2 a}$ & 400 \\
& & $W_{2 a}$ & 400
\end{tabular}

\begin{tabular}{ll|ll}
\multicolumn{4}{c}{ IIb. Luxury goods } \\
\hline \multicolumn{4}{c}{ Firms IIb } \\
\hline $\boldsymbol{M}$ & $\mathbf{2 0 0}$ & $M$ & 200 \\
$\boldsymbol{L g}$ & $\mathbf{4 0 0}$ & $M p_{2 b}$ & 400 \\
$M p$ & 200 & $Q_{2 b}$ & 100 \\
& & $W_{2 b}$ & 100
\end{tabular}

\begin{tabular}{ll|ll}
\multicolumn{4}{c}{ Capitalist wealth-owners I } \\
\hline$Q \quad 500$ & $Q$ & 500
\end{tabular}
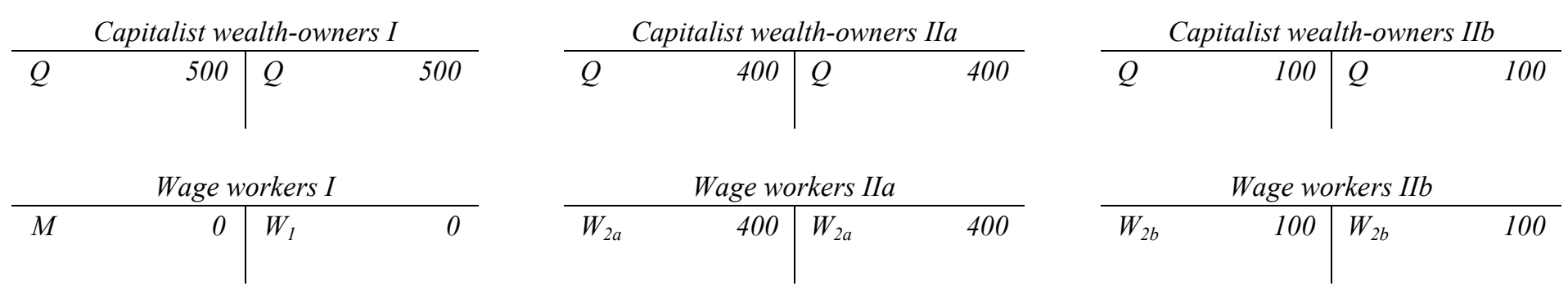

\begin{tabular}{lr|ll}
\multicolumn{4}{c}{ Capitalist Households I } \\
\hline $\boldsymbol{M}$ & $\mathbf{0}$ & $\mathrm{C}$ & 1000 \\
$\boldsymbol{Q}$ & $\mathbf{5 0 0}$ & & \\
$\mathbf{S g}$ & $\mathbf{3 0 0}$ & \\
$\mathbf{L g}$ & $\mathbf{2 0 0}$ & \\
\multicolumn{4}{c}{ Working Households I } \\
\hline $\mathrm{Sg}$ & 1000 & $\mathrm{C}$ & 1000
\end{tabular}
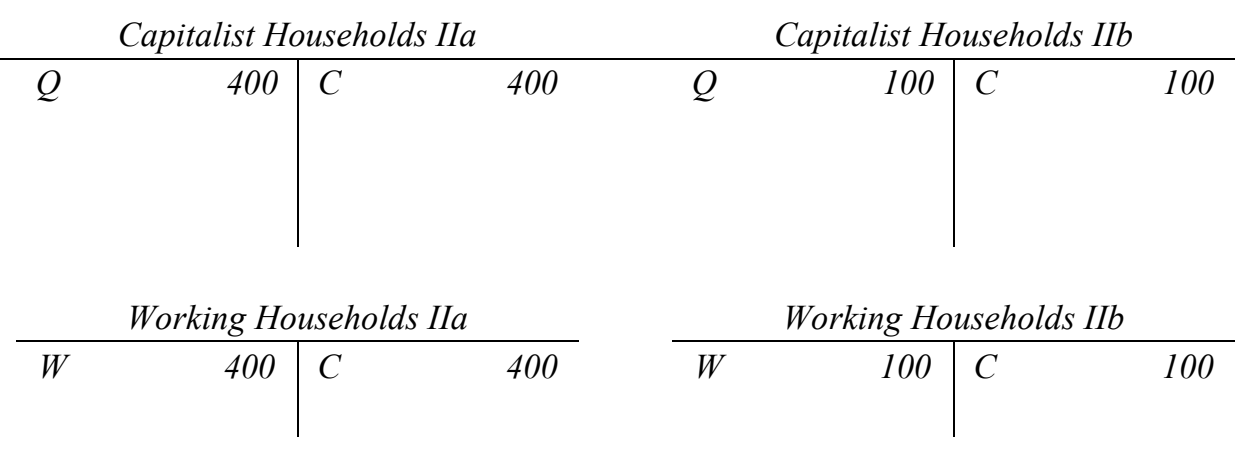
(10) Firms I transfer the capital income for $£ 500$ to the wealth-owners I before having moneyed their profit.

\begin{tabular}{lr|lr}
\multicolumn{4}{c}{ I. Means of production } \\
\hline \multicolumn{4}{c}{ Firms I } \\
\hline $\boldsymbol{M}$ & $\mathbf{5 0 0}$ & $M$ & 1000 \\
$M p$ & 4500 & $M p_{1}$ & 4000 \\
& & $Q_{1}$ & 0 \\
& & $W_{1}$ & 0
\end{tabular}

\begin{tabular}{lr|lr}
\multicolumn{4}{c}{ IIa. Subsistence goods (necessaries) } \\
\hline \multicolumn{4}{c}{ Firms IIa } \\
\hline $\boldsymbol{M}$ & $\mathbf{3 0 0}$ & $M$ & 300 \\
$\mathbf{S g}$ & $\mathbf{1 1 0 0}$ & $\mathrm{Mp}_{2 a}$ & 1600 \\
$\mathrm{Mp}$ & 1300 & $Q_{2 a}$ & 400 \\
& & $W_{2 a}$ & 400
\end{tabular}

\begin{tabular}{ll|ll}
\multicolumn{4}{c}{ IIb. Luxury goods } \\
\hline \multicolumn{4}{c}{ Firms IIb } \\
\hline $\boldsymbol{M}$ & $\mathbf{2 0 0}$ & $M$ & 200 \\
$\boldsymbol{L g}$ & $\mathbf{4 0 0}$ & $\mathrm{Mp} p_{2 b}$ & 400 \\
$\mathrm{Mp}$ & 200 & $Q_{2 b}$ & 100 \\
& & $W_{2 b}$ & 100
\end{tabular}
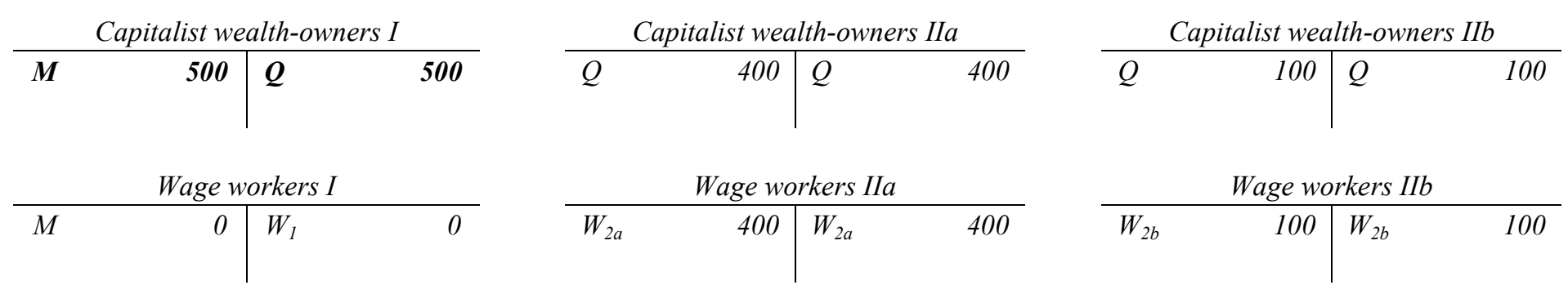

\begin{tabular}{lr|ll}
\multicolumn{4}{c}{ Capitalist Households I } \\
\hline $\boldsymbol{M}$ & $\boldsymbol{0}$ & $\mathrm{C}$ & 1000 \\
$\boldsymbol{Q}$ & $\mathbf{5 0 0}$ & & \\
$\mathrm{Sg}$ & 300 & \\
$\mathrm{Lg}$ & 200 & \\
\multicolumn{4}{c}{ Working Households I } \\
\hline $\mathrm{Sg}$ & 1000 & $\mathrm{C}$ & 1000
\end{tabular}
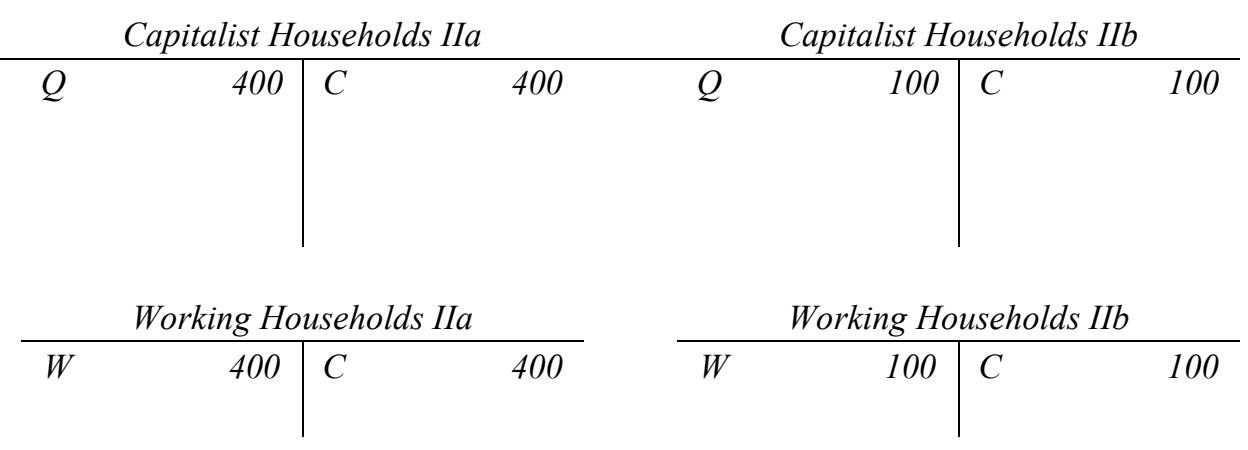
(11) Wealth-owners I transfer $£ 500$ to the capitalist households I. End of circulation process of wealth-owners I.

\begin{tabular}{lr|lr}
\multicolumn{4}{c}{ I. Means of production } \\
\hline \multicolumn{4}{c}{ Firms I } \\
\hline $\boldsymbol{M}$ & $\mathbf{5 0 0}$ & $M$ & 1000 \\
$M p$ & 4500 & $M p_{1}$ & 4000 \\
& & $Q_{1}$ & 0 \\
& & $W_{1}$ & 0
\end{tabular}

\begin{tabular}{lr|lr}
\multicolumn{4}{c}{ IIa. Subsistence goods (necessaries) } \\
\hline \multicolumn{4}{c}{ Firms IIa } \\
\hline $\boldsymbol{M}$ & $\mathbf{3 0 0}$ & $M$ & 300 \\
$\mathbf{S g}$ & $\mathbf{1 1 0 0}$ & $\mathrm{Mp} p_{2 a}$ & 1600 \\
$\mathrm{Mp}$ & 1300 & $Q_{2 a}$ & 400 \\
& & $W_{2 a}$ & 400
\end{tabular}

\begin{tabular}{ll|ll}
\multicolumn{4}{c}{ IIb. Luxury goods } \\
\hline \multicolumn{4}{c}{ Firms IIb } \\
\hline $\boldsymbol{M}$ & $\mathbf{2 0 0}$ & $M$ & 200 \\
$\boldsymbol{L g}$ & $\mathbf{4 0 0}$ & $M p_{2 b}$ & 400 \\
$M p$ & 200 & $Q_{2 b}$ & 100 \\
& & $W_{2 b}$ & 100
\end{tabular}
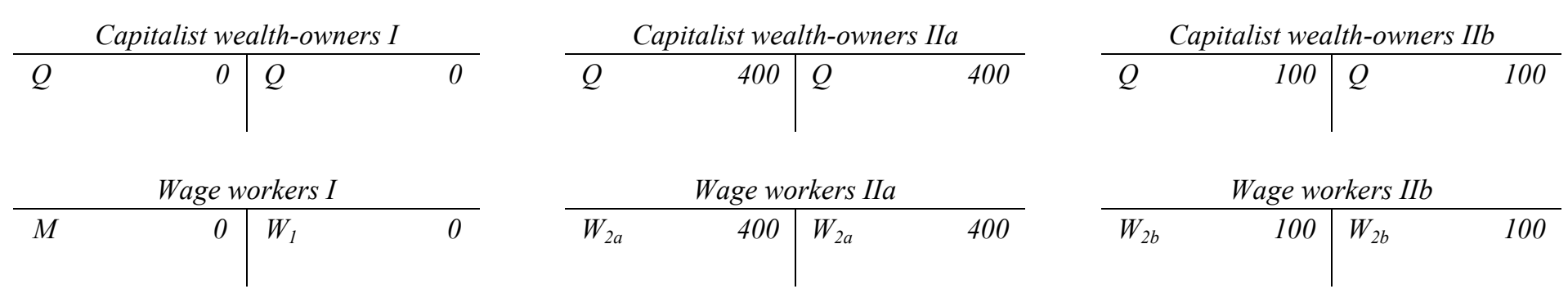

\begin{tabular}{lr|ll}
\multicolumn{4}{c}{ Capitalist Households I } \\
\hline $\boldsymbol{M}$ & $\mathbf{5 0 0}$ & $\mathrm{C}$ & 1000 \\
$\boldsymbol{Q}$ & $\mathbf{0}$ & & \\
$\mathrm{Sg}$ & 300 & \\
$\mathrm{Lg}$ & 200 & \\
\multicolumn{4}{c}{ Working Households I } \\
\hline $\mathrm{Sg}$ & 1000 & $\mathrm{C}$ & 1000
\end{tabular}
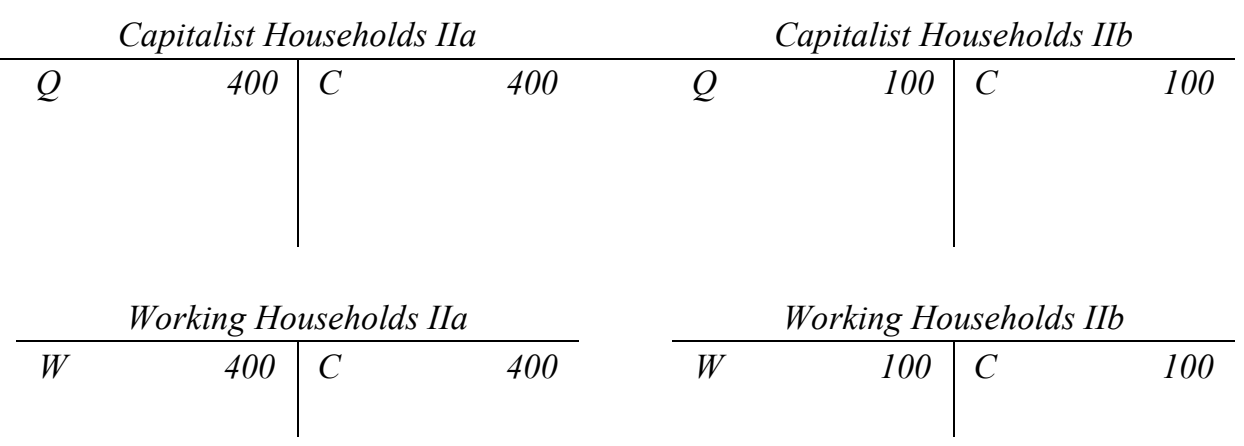
(12) Capitalist households I spend $£ 300$ to buy necessaries from firms IIa; they also spend $£ 200$ to buy luxury goods from firms IIb.

\begin{tabular}{lr|lr}
\multicolumn{4}{c}{ I. Means of production } \\
\hline \multicolumn{4}{c}{ Firms I } \\
\hline $\boldsymbol{M}$ & $\mathbf{5 0 0}$ & $M$ & 1000 \\
$M p$ & 4500 & $M p_{1}$ & 4000 \\
& & $Q_{l}$ & 0 \\
& & $W_{l}$ & 0
\end{tabular}

IIa. Subsistence goods (necessaries)

\begin{tabular}{lr|lr}
\multicolumn{4}{c}{ Firms IIa } \\
\hline $\boldsymbol{M}$ & $\mathbf{6 0 0}$ & $M$ & 300 \\
$\boldsymbol{S g}$ & $\mathbf{8 0 0}$ & $M p_{2 a}$ & 1600 \\
$M p$ & 1300 & $Q_{2 a}$ & 400 \\
& & $W_{2 a}$ & 400
\end{tabular}
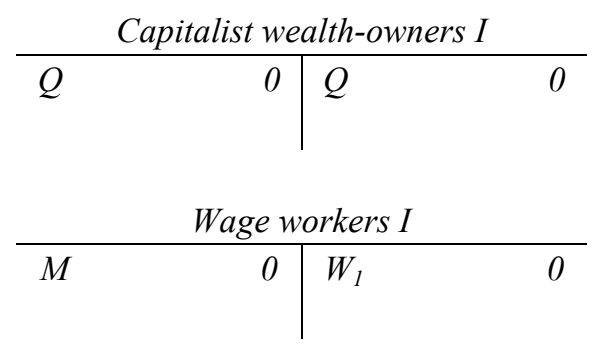
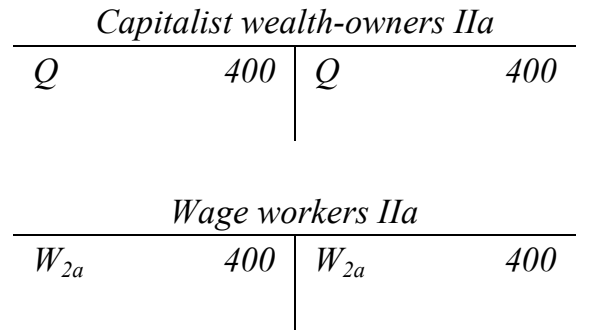

IIb. Luxury goods

\begin{tabular}{ll|lc}
\multicolumn{4}{c}{ Firms IIb } \\
\hline $\boldsymbol{M}$ & $\mathbf{4 0 0}$ & $M$ & 200 \\
$\boldsymbol{L g}$ & $\mathbf{2 0 0}$ & $M p_{2 b}$ & 400 \\
$M p$ & 200 & $Q_{2 b}$ & 100 \\
& & $W_{2 b}$ & 100
\end{tabular}
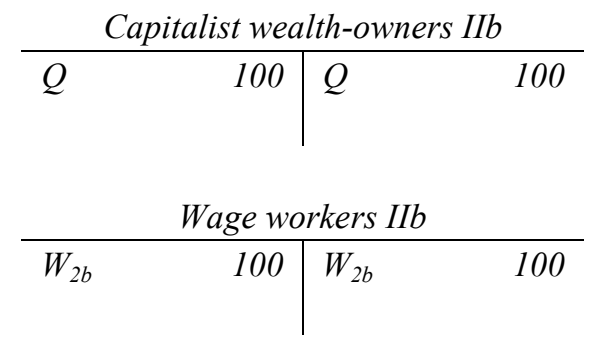

\begin{tabular}{|c|c|c|c|c|c|c|c|c|c|c|c|}
\hline \multicolumn{4}{|c|}{ Capitalist Households I } & \multicolumn{4}{|c|}{ Capitalist Households IIa } & \multicolumn{4}{|c|}{ Capitalist Households IIb } \\
\hline$M$ & 0 & $C$ & 1000 & $Q$ & 400 & $C$ & 400 & $Q$ & 100 & $C$ & 100 \\
\hline$Q$ & 0 & & & & & & & & & & \\
\hline$S g$ & 600 & & & & & & & & & & \\
\hline $\operatorname{Lg}$ & 400 & & & & & & & & & & \\
\hline \multicolumn{4}{|c|}{ Working Households I } & \multicolumn{4}{|c|}{ Working Households IIa } & \multicolumn{4}{|c|}{ Working Households IIb } \\
\hline$S g$ & 1000 & $C$ & 1000 & $W$ & 400 & $C$ & 400 & $W$ & 100 & $C$ & 100 \\
\hline
\end{tabular}


(13) Firms IIa buy means of production for $£ 300$ from capitalists I. And firms IIb buy means of production for $£ 200$ from firms I. End of circulation process between firms I and firms IIa and IIb.

\begin{tabular}{lr|lr}
\multicolumn{4}{c}{ I. Means of production } \\
\hline \multicolumn{4}{c}{ Firms I } \\
\hline $\boldsymbol{M}$ & $\mathbf{1 0 0 0}$ & $M$ & 1000 \\
$\boldsymbol{M p}$ & $\mathbf{4 0 0 0}$ & $M p_{1}$ & 4000 \\
& & $Q_{1}$ & 0 \\
& & $W_{1}$ & 0
\end{tabular}

\begin{tabular}{cr|lr}
\multicolumn{4}{c}{ IIa. Subsistence goods (necessaries) } \\
\hline \multicolumn{4}{c}{ Firms IIa } \\
\hline $\boldsymbol{M}$ & $\mathbf{3 0 0}$ & $M$ & 300 \\
$\mathrm{Sg}$ & 800 & $M p_{2 a}$ & 1600 \\
$\mathbf{M p}$ & $\mathbf{1 6 0 0}$ & $Q_{2 a}$ & 400 \\
& & $W_{2 a}$ & 400
\end{tabular}

\begin{tabular}{ll|ll}
\multicolumn{4}{c}{ IIb. Luxury goods } \\
\hline \multicolumn{4}{c}{ Firms IIb } \\
\hline $\boldsymbol{M}$ & $\mathbf{2 0 0}$ & $M$ & 200 \\
$\mathrm{Lg}$ & 200 & $\mathrm{Mp} p_{2 b}$ & 400 \\
$\boldsymbol{M p}$ & 400 & $Q_{2 b}$ & 100 \\
& & $W_{2 b}$ & 100
\end{tabular}
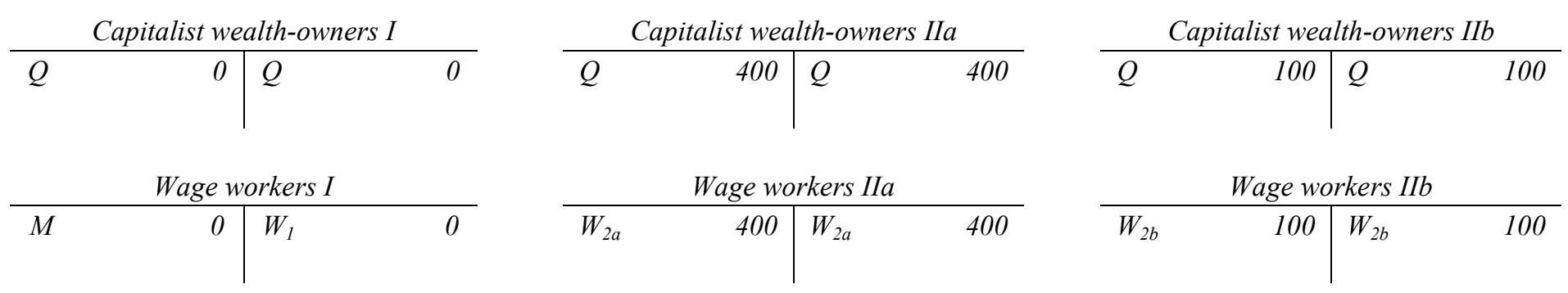

\begin{tabular}{lr|ll}
\multicolumn{5}{c}{ Capitalist Households I } \\
\hline$M$ & 0 & $C$ & 1000 \\
$Q$ & 0 & \\
$S g$ & 600 & \\
$L g$ & 400 & \\
\multicolumn{4}{c}{ Working Households I } \\
\hline$S g$ & 1000 & $C$ & 1000
\end{tabular}

\begin{tabular}{|c|c|c|c|}
\hline \multicolumn{4}{|c|}{ Capitalist Households IIa } \\
\hline$Q$ & 400 & $C$ & 400 \\
\hline \multicolumn{4}{|c|}{ Working Households IIa } \\
\hline$W$ & 400 & $C$ & 400 \\
\hline
\end{tabular}
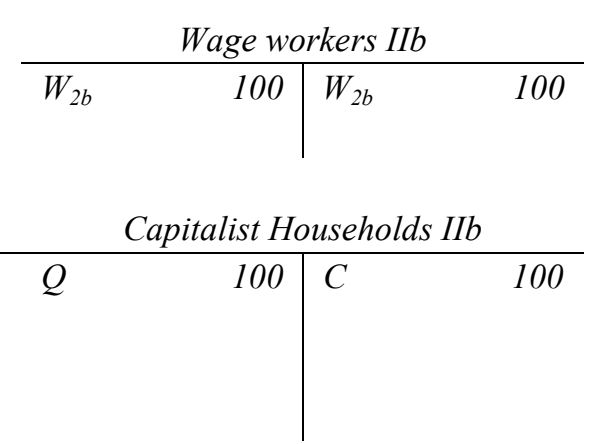

\begin{tabular}{cc|ll}
\multicolumn{4}{c}{ Working Households IIb } \\
\hline$W$ & 100 & C & 100
\end{tabular}


(14) Firms IIb pay $£ 100$ to the workers. End of wage contract of workers IIb. The workers are fired and the new unemployed exwage workers go back to the "reserve army of the unvoluntarily unemployed".

\begin{tabular}{lr|lr}
\multicolumn{4}{c}{ I. Means of production } \\
\hline \multicolumn{4}{c}{ Firms I } \\
\hline$M$ & 1000 & $M$ & 1000 \\
$M p$ & 4000 & $M p_{1}$ & 4000 \\
& & $Q_{1}$ & 0 \\
& & $W_{1}$ & 0
\end{tabular}

IIa. Subsistence goods (necessaries)

\begin{tabular}{lr|lr}
\multicolumn{4}{c}{ Firms IIa } \\
\hline$M$ & 300 & $M$ & 300 \\
$S g$ & 800 & $M p_{2 a}$ & 1600 \\
$M p$ & 1600 & $Q_{2 a}$ & 400 \\
& & $W_{2 a}$ & 400
\end{tabular}
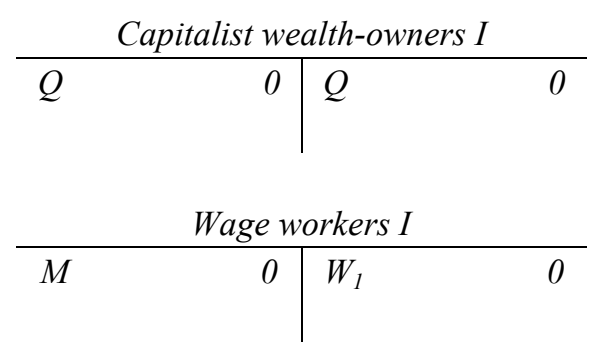
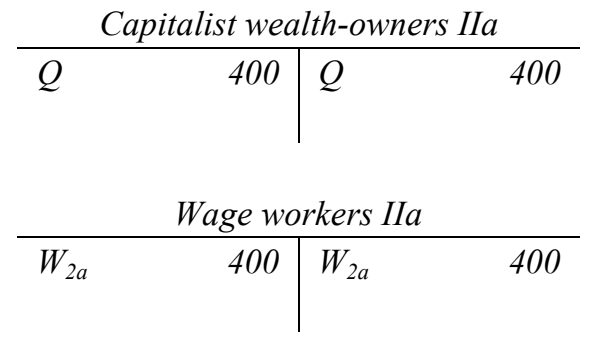

IIb. Luxury goods

\begin{tabular}{ll|lr}
\multicolumn{4}{c}{ Firms $I$ Ib } \\
\hline $\boldsymbol{M}$ & $\mathbf{1 0 0}$ & $M$ & 200 \\
$\mathrm{Lg}$ & 200 & $M_{2 b}$ & 400 \\
$\mathrm{Mp}$ & 400 & $Q_{2 b}$ & 100 \\
& & $\boldsymbol{W}_{2 \boldsymbol{b}}$ & $\mathbf{0}$
\end{tabular}
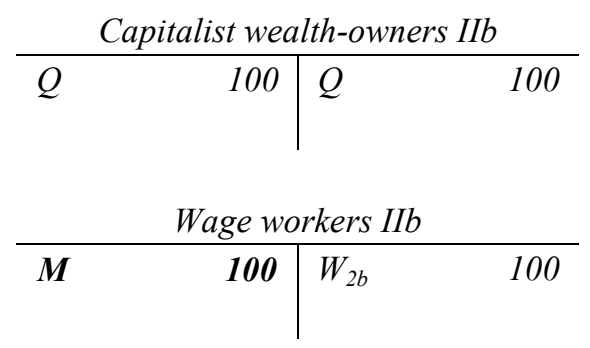

\begin{tabular}{|c|c|c|c|c|c|c|c|c|c|c|c|}
\hline \multicolumn{4}{|c|}{ Capitalist Households I } & \multicolumn{4}{|c|}{ Capitalist Households IIa } & \multicolumn{4}{|c|}{ Capitalist Households IIb } \\
\hline$M$ & 0 & $C$ & 1000 & $Q$ & 400 & $C$ & 400 & $Q$ & 100 & $C$ & 100 \\
\hline$Q$ & 0 & & & & & & & & & & \\
\hline$S g$ & 600 & & & & & & & & & & \\
\hline$L g$ & 400 & & & & & & & & & & \\
\hline \multicolumn{4}{|c|}{ Working Households I } & \multicolumn{4}{|c|}{ Working Households IIa } & \multicolumn{4}{|c|}{ Working Households IIb } \\
\hline$S g$ & 1000 & $C$ & 1000 & $W$ & 400 & $C$ & 400 & $W$ & 100 & $C$ & 100 \\
\hline
\end{tabular}


(15) Workers IIb transfer $£ 100$ to working households I.

\begin{tabular}{lr|lr}
\multicolumn{4}{c}{ I. Means of production } \\
\hline \multicolumn{4}{c}{ Firms I } \\
\hline$M$ & 1000 & $M$ & 1000 \\
$M p$ & 4000 & $M p_{1}$ & 4000 \\
& & $Q_{1}$ & 0 \\
& & $W_{1}$ & 0
\end{tabular}

\begin{tabular}{cr|lr}
\multicolumn{4}{c}{ IIa. Subsistence goods (necessaries) } \\
\hline \multicolumn{4}{c}{ Firms IIa } \\
\hline$M$ & 300 & $M$ & 300 \\
$S g$ & 800 & $M p_{2 a}$ & 1600 \\
$M p$ & 1600 & $Q_{2 a}$ & 400 \\
& & $W_{2 a}$ & 400
\end{tabular}

\begin{tabular}{lr|lr}
\multicolumn{4}{c}{ IIb. Luxury goods } \\
\hline \multicolumn{4}{c}{ Firms IIb } \\
\hline$M$ & 100 & $M$ & 200 \\
$L g$ & 200 & $M p_{2 b}$ & 400 \\
$M p$ & 400 & $Q_{2 b}$ & 100 \\
& & $W_{2 b}$ & 0
\end{tabular}
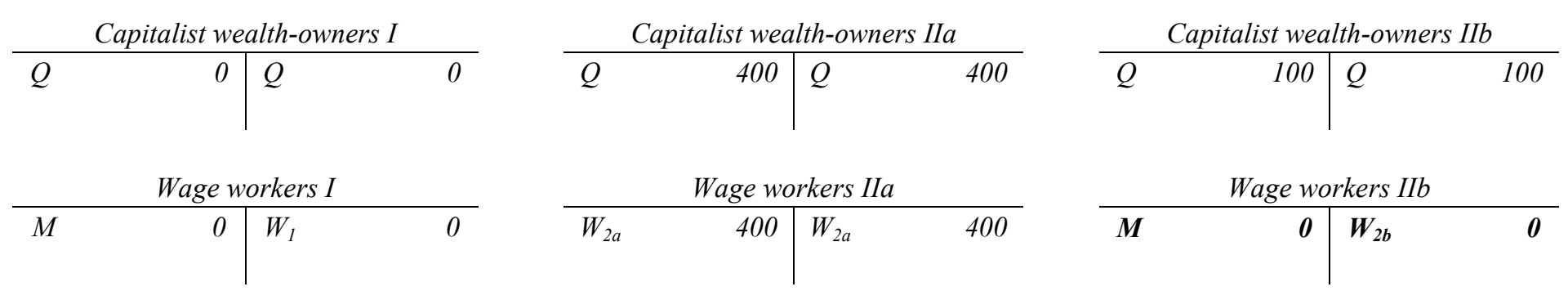

\begin{tabular}{lr|ll}
\multicolumn{5}{c}{ Capitalist Households I } \\
\hline$M$ & 0 & $C$ & 1000 \\
$Q$ & 0 & & \\
$S g$ & 600 & \\
$L g$ & 400 & \\
\multicolumn{4}{c}{ Working Households I } \\
\hline$S g$ & 1000 & C & 1000
\end{tabular}
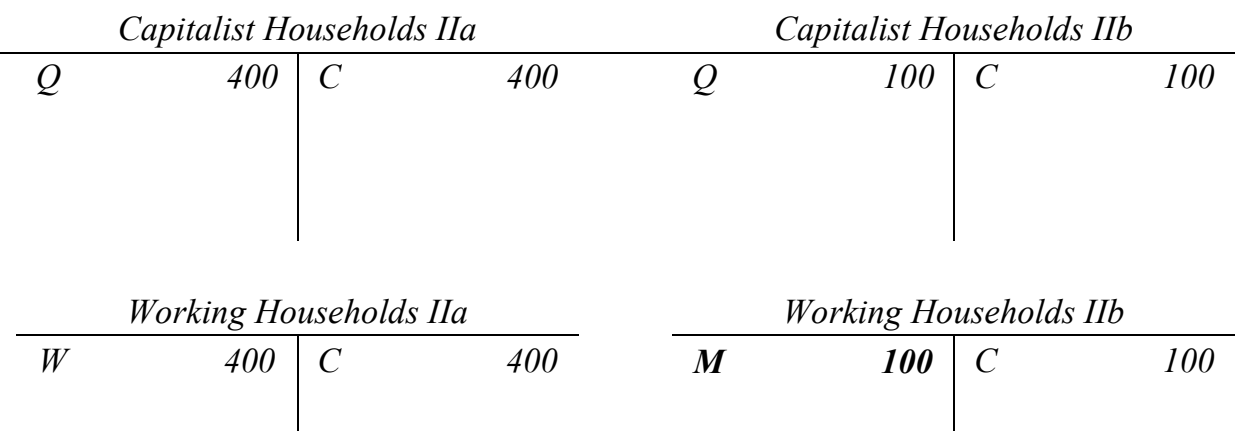
(16) Working households IIb by subsistence goods for $£ 100$ from firms IIa. End of circulation process of workers IIb.

\begin{tabular}{cr|lr}
\multicolumn{4}{c}{ I. Means of production } \\
\hline \multicolumn{4}{c}{ Firms I } \\
\hline$M$ & 1000 & $M$ & 1000 \\
$M p$ & 4000 & $M p_{1}$ & 4000 \\
& & $Q_{1}$ & 0 \\
& & $W_{1}$ & 0
\end{tabular}

\begin{tabular}{lr|lr}
\multicolumn{4}{c}{ IIa. Subsistence goods (necessaries) } \\
\hline \multicolumn{4}{c}{ Firms IIa } \\
\hline $\boldsymbol{M}$ & $\mathbf{4 0 0}$ & $M$ & 300 \\
$\mathbf{S g}$ & $\mathbf{7 0 0}$ & $M p_{2 a}$ & 1600 \\
$\mathrm{Mp}$ & 1600 & $Q_{2 a}$ & 400 \\
& & $W_{2 a}$ & 400
\end{tabular}

\begin{tabular}{lr|lr}
\multicolumn{4}{c}{ IIb. Luxury goods } \\
\hline \multicolumn{4}{c}{ Firms IIb } \\
\hline$M$ & 100 & $M$ & 200 \\
$L g$ & 200 & $M p_{2 b}$ & 400 \\
$M p$ & 400 & $Q_{2 b}$ & 100 \\
& & $W_{2 b}$ & 0
\end{tabular}
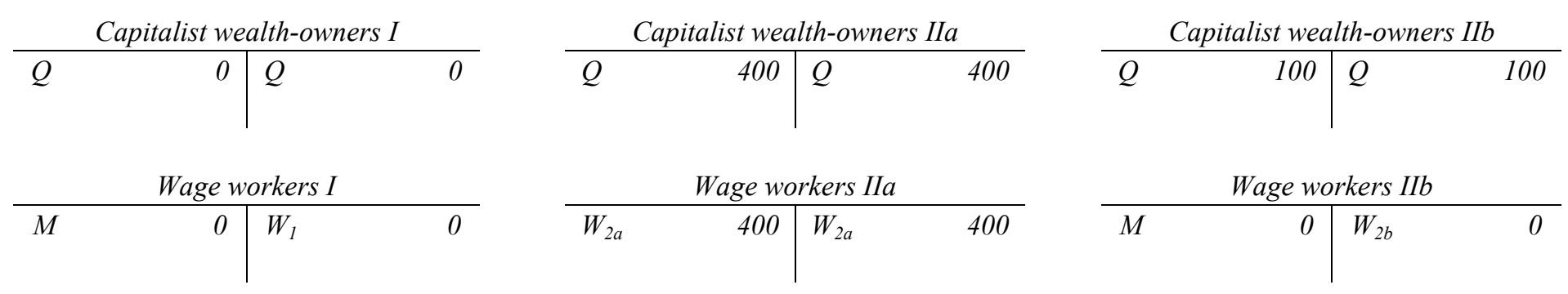

\begin{tabular}{lr|ll}
\multicolumn{4}{c}{ Capitalist Households I } \\
\hline$M$ & 0 & $C$ & 1000 \\
$Q$ & 0 & & \\
$S g$ & 600 & \\
$L g$ & 400 & \\
\multicolumn{4}{c}{ Working Households I } \\
\hline Sg & 1000 & C & 1000
\end{tabular}
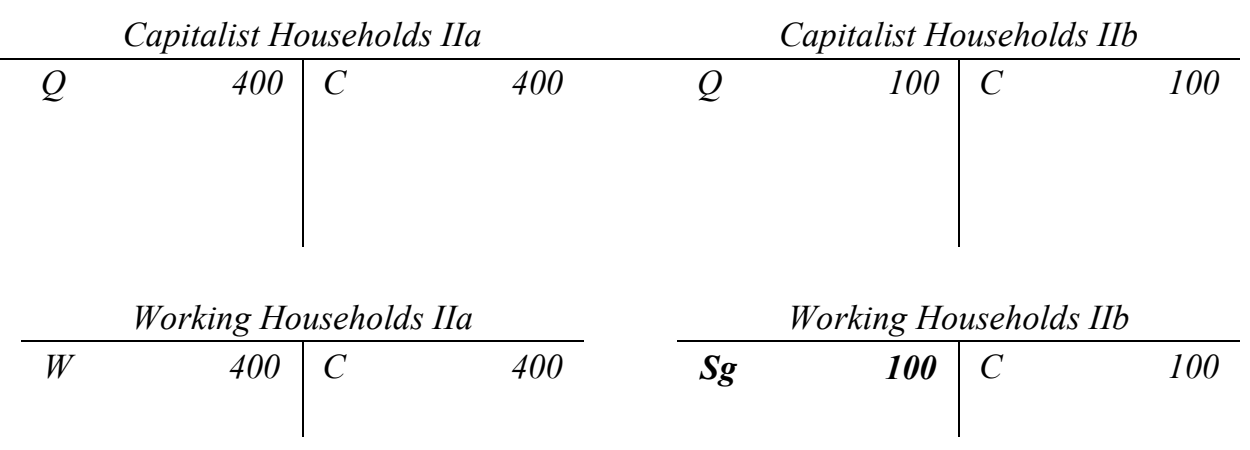
(17) Firms IIa pay wages for $£ 400$ to the workers. End of wage labour contract of workers IIa. Unemployed ex-wage workers go back to the "reserve army of the unvoluntarily unemployed".

\begin{tabular}{lr|lr}
\multicolumn{4}{c}{ I. Means of production } \\
\hline \multicolumn{4}{c}{ Firms I } \\
\hline$M$ & 1000 & $M$ & 1000 \\
$M p$ & 4000 & $M p_{1}$ & 4000 \\
& & $Q_{1}$ & 0 \\
& & $W_{1}$ & 0
\end{tabular}

IIa. Subsistence goods (necessaries)

\begin{tabular}{lr|lr}
\multicolumn{4}{c}{ Firms II } \\
\hline $\boldsymbol{M}$ & $\boldsymbol{0}$ & $M$ & 300 \\
$\mathrm{Sg}$ & 700 & $M p_{2 a}$ & 1600 \\
$\mathrm{Mp}$ & 1600 & $Q_{2 a}$ & 400 \\
& & $\boldsymbol{W}_{2 a}$ & $\boldsymbol{0}$
\end{tabular}
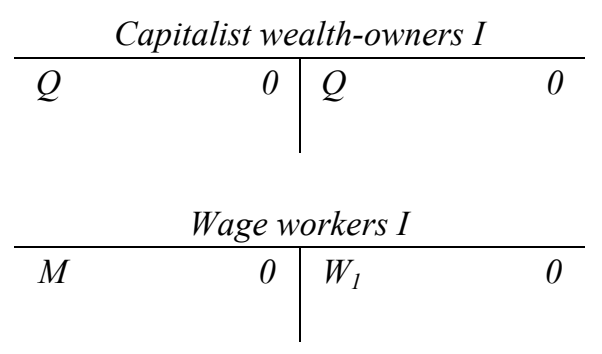
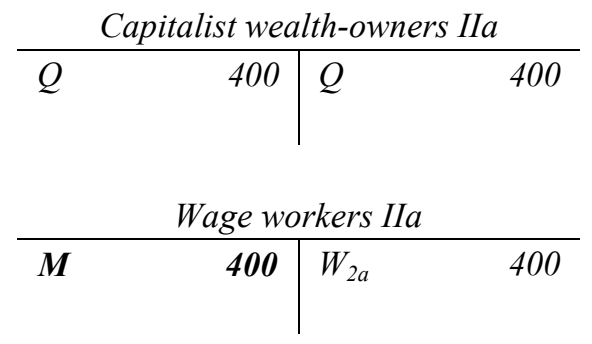

IIb. Luxury goods

\begin{tabular}{ll|lr}
\multicolumn{4}{c}{ Firms IIb } \\
\hline$M$ & 100 & $M$ & 200 \\
$\mathrm{Lg}$ & 200 & $M p_{2 b}$ & 400 \\
$\mathrm{Mp}$ & 400 & $Q_{2 b}$ & 100 \\
& & $W_{2 b}$ & 0
\end{tabular}
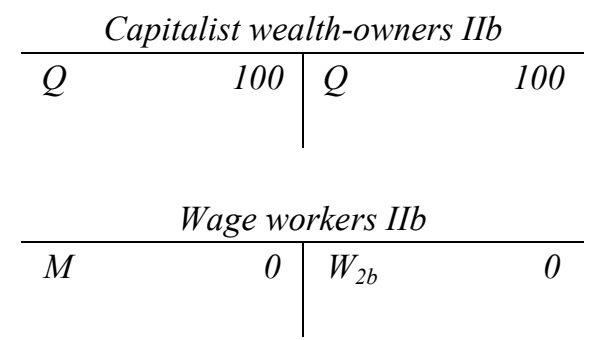

\begin{tabular}{|c|c|c|c|c|c|c|c|c|c|c|c|}
\hline \multicolumn{4}{|c|}{ Capitalist Households I } & \multicolumn{4}{|c|}{ Capitalist Households IIa } & \multicolumn{4}{|c|}{ Capitalist Households IIb } \\
\hline$M$ & 0 & $C$ & 1000 & $Q$ & 400 & $C$ & 400 & $Q$ & 100 & $C$ & 100 \\
\hline$Q$ & 0 & & & & & & & & & & \\
\hline$S g$ & 600 & & & & & & & & & & \\
\hline$L g$ & 400 & & & & & & & & & & \\
\hline \multicolumn{4}{|c|}{ Working Households I } & \multicolumn{4}{|c|}{ Working Households IIa } & \multicolumn{4}{|c|}{ Working Households IIb } \\
\hline$S g$ & 1000 & $C$ & 1000 & $W$ & 400 & $C$ & 400 & $S g$ & 100 & $C$ & 100 \\
\hline
\end{tabular}


(18) Workers IIa transfer for $£ 400$ to the working households. End of wage contract of workers IIa. The workers are fired and the new unemployed ex-wage workers go back to the labour market.

\begin{tabular}{lr|lr}
\multicolumn{4}{c}{ I. Means of production } \\
\hline \multicolumn{4}{c}{ Firms I } \\
\hline$M$ & 1000 & $M$ & 1000 \\
$M p$ & 4000 & $M p_{1}$ & 4000 \\
& & $Q_{1}$ & 0 \\
& & $W_{1}$ & 0
\end{tabular}

\begin{tabular}{lr|lr}
\multicolumn{4}{c}{ IIa. Subsistence goods (necessaries) } \\
\hline \multicolumn{4}{c}{ Firms IIa } \\
\hline$M$ & 0 & $M$ & 300 \\
$S g$ & 700 & $M p_{2 a}$ & 1600 \\
$M p$ & 1600 & $Q_{2 a}$ & 400 \\
& & $W_{2 a}$ & 0
\end{tabular}

\begin{tabular}{lr|lr}
\multicolumn{4}{c}{ IIb. Luxury goods } \\
\hline \multicolumn{4}{c}{ Firms IIb } \\
\hline$M$ & 100 & $M$ & 200 \\
$L g$ & 200 & $M p_{2 b}$ & 400 \\
$M p$ & 400 & $Q_{2 b}$ & 100 \\
& & $W_{2 b}$ & 0
\end{tabular}
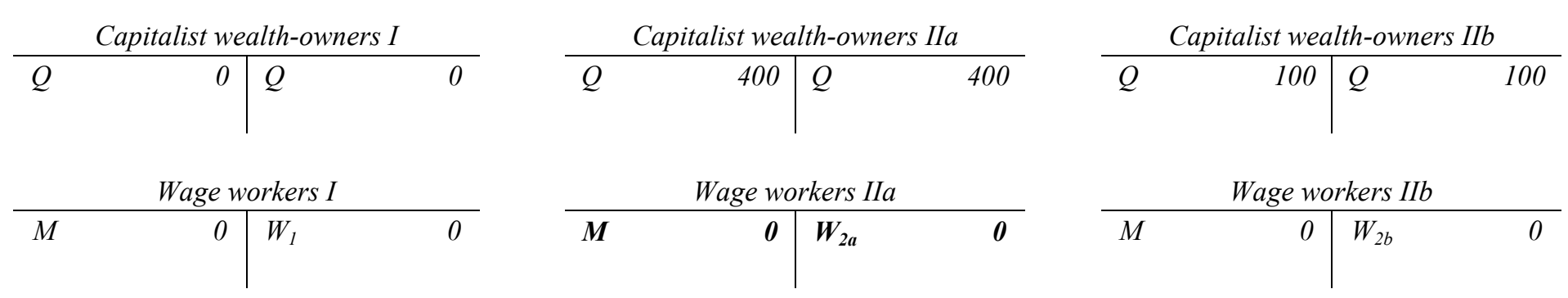

\begin{tabular}{lr|ll}
\multicolumn{5}{c}{ Capitalist Households I } \\
\hline$M$ & 0 & $C$ & 1000 \\
$Q$ & 0 & & \\
$S g$ & 600 & \\
$\mathrm{Lg}$ & 400 & \\
\multicolumn{4}{c}{ Working Households I } \\
\hline $\mathrm{Sg}$ & 1000 & $\mathrm{C}$ & 1000
\end{tabular}

\begin{tabular}{rr|ll}
\multicolumn{4}{c}{ Capitalist Households IIa } \\
\hline Q & 400 & C & 400 \\
& & \\
& & \\
\multicolumn{4}{c}{ Working Households IIa } \\
\hline M & $\mathbf{4 0 0}$ & C & 400
\end{tabular}

\begin{tabular}{rr|ll}
\multicolumn{4}{c}{ Capitalist Households IIb } \\
\hline & 100 & $C$ & 100 \\
& & & \\
& & \\
\multicolumn{4}{r}{ Working Households IIb } \\
\hline $\mathrm{Sg} \quad 100$ & $\mathrm{C}$ & 100
\end{tabular}


(19) Working households IIa buy subsistence goods for $£ 400$ from firms IIa.

\begin{tabular}{lr|lr}
\multicolumn{4}{c}{ I. Means of production } \\
\hline \multicolumn{4}{c}{ Firms I } \\
\hline$M$ & 1000 & $M$ & 1000 \\
$M p$ & 4000 & $M p_{1}$ & 4000 \\
& & $Q_{1}$ & 0 \\
& & $W_{1}$ & 0
\end{tabular}

\begin{tabular}{lr|lr}
\multicolumn{4}{c}{ IIa. Subsistence goods (necessaries) } \\
\hline \multicolumn{4}{c}{ Firms IIa } \\
\hline $\boldsymbol{M}$ & $\mathbf{4 0 0}$ & $M$ & 300 \\
$\mathbf{S g}$ & 300 & $M p_{2 a}$ & 1600 \\
$\mathrm{Mp}$ & 1600 & $Q_{2 a}$ & 400 \\
& & $W_{2 a}$ & 0
\end{tabular}

\begin{tabular}{lr|lr}
\multicolumn{4}{c}{ IIb. Luxury goods } \\
\hline \multicolumn{4}{c}{ Firms IIb } \\
\hline$M$ & 100 & $M$ & 200 \\
$L g$ & 200 & $M p_{2 b}$ & 400 \\
$M p$ & 400 & $Q_{2 b}$ & 100 \\
& & $W_{2 b}$ & 0
\end{tabular}
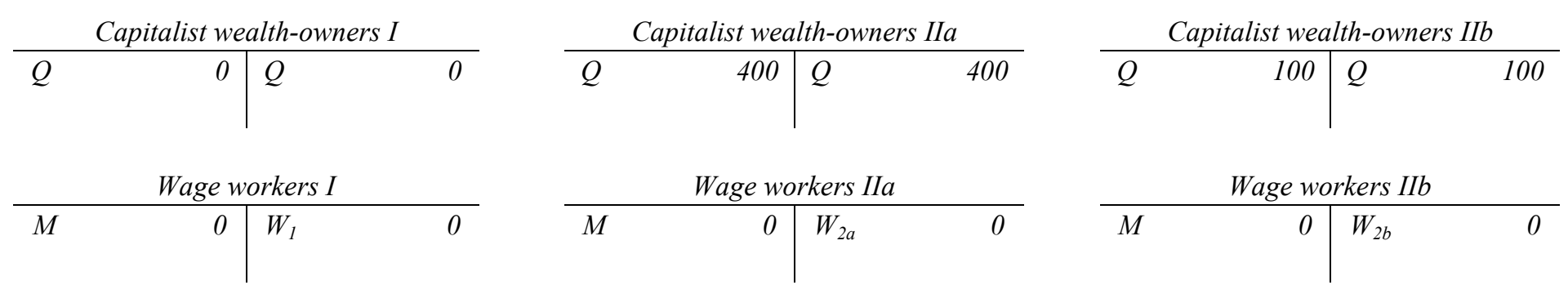

\begin{tabular}{lr|ll}
\multicolumn{5}{c}{ Capitalist Households I } \\
\hline$M$ & 0 & $C$ & 1000 \\
$Q$ & 0 & & \\
$S g$ & 600 & \\
$L g$ & 400 & \\
\multicolumn{4}{c}{ Working Households I } \\
\hline$S g$ & 1000 & C & 1000
\end{tabular}
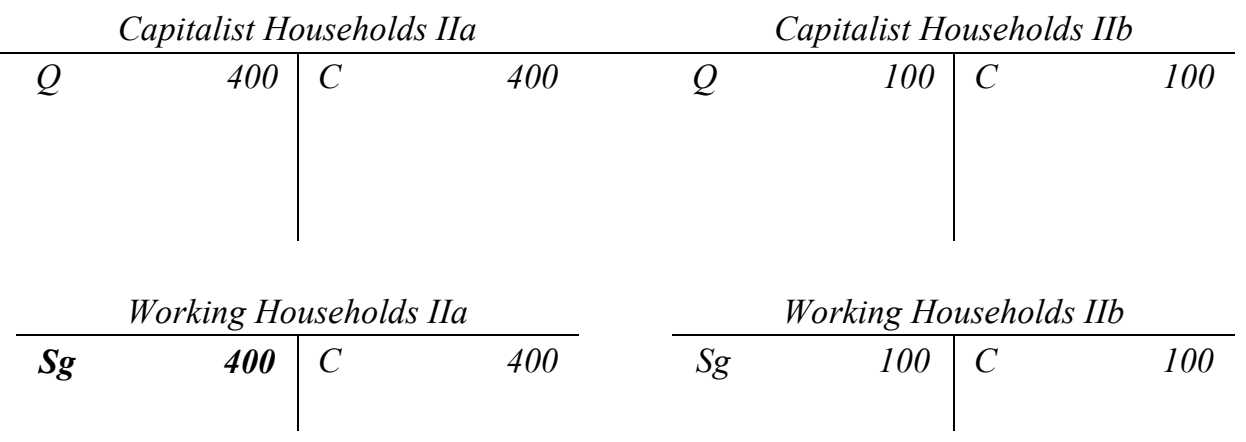
(20) Firms IIa transfer the capital income for $£ 100$ to the wealth-owners IIa before having moneyed their profit.

\begin{tabular}{lr|lr}
\multicolumn{4}{c}{ I. Means of production } \\
\hline \multicolumn{4}{c}{ Firms I } \\
\hline$M$ & 1000 & $M$ & 1000 \\
$M p$ & 4000 & $M p_{1}$ & 4000 \\
& & $Q_{l}$ & 0 \\
& & $W_{l}$ & 0
\end{tabular}

\begin{tabular}{cr|lr}
\multicolumn{4}{c}{ IIa. Subsistence goods (necessaries) } \\
\hline \multicolumn{4}{c}{ Firms IIa } \\
\hline $\boldsymbol{M}$ & 300 & $M$ & 300 \\
$\mathrm{Sg}$ & 300 & $M p_{2 a}$ & 1600 \\
$\mathrm{Mp}$ & 1600 & $\boldsymbol{Q}_{2 a}$ & 300 \\
& & $W_{2 a}$ & 0
\end{tabular}

\begin{tabular}{lr|lr}
\multicolumn{4}{c}{ IIb. Luxury goods } \\
\hline \multicolumn{4}{c}{ Firms IIb } \\
\hline$M$ & 100 & $M$ & 200 \\
$L g$ & 200 & $M p_{2 b}$ & 400 \\
$M p$ & 400 & $Q_{2 b}$ & 100 \\
& & $W_{2 b}$ & 0
\end{tabular}
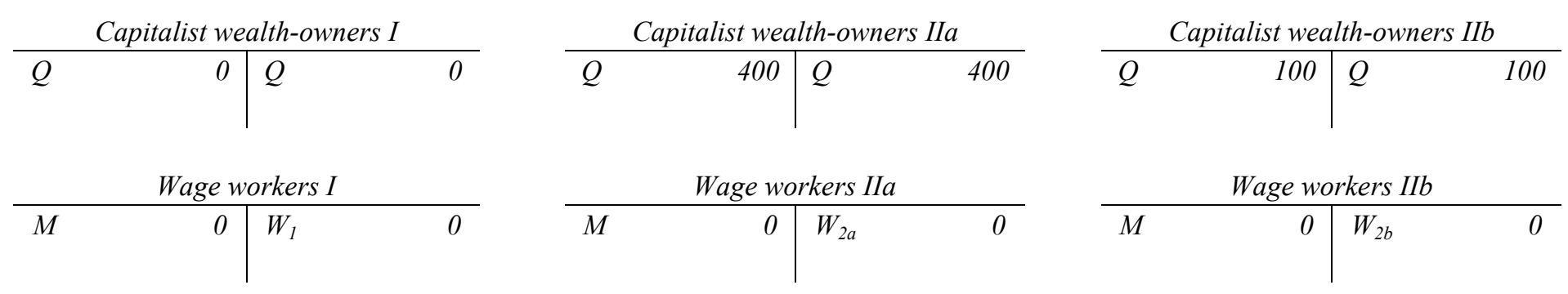

\begin{tabular}{lr|ll}
\multicolumn{4}{c}{ Capitalist Households I } \\
\hline$M$ & 0 & $C$ & 1000 \\
$Q$ & 0 & \\
$\mathrm{Sg}$ & 600 & \\
$\mathrm{Lg}$ & 400 & \\
\multicolumn{4}{c}{ Working Households I } \\
\hline $\mathrm{Sg}$ & 1000 & $\mathrm{C}$ & 1000
\end{tabular}

\begin{tabular}{cr|ll}
\multicolumn{5}{c}{ Capitalist Households IIa } \\
\hline $\boldsymbol{M}$ & $\mathbf{1 0 0}$ & $\mathrm{C}$ & 400 \\
$\mathbf{Q}$ & & & \\
& & & \\
& & \\
\multicolumn{4}{c}{ Working Households IIa } \\
\hline $\mathrm{Sg}$ & 400 & $\mathrm{C}$ & 400
\end{tabular}

\begin{tabular}{rr|ll}
\multicolumn{5}{c}{ Capitalist Households IIb } \\
\hline & 100 & $C$ & 100 \\
& & & \\
\multicolumn{4}{c}{ Working Households IIb } \\
\hline $\mathrm{Sg} \quad 100$ & $\mathrm{C}$ & 100
\end{tabular}


(21) Wealth-owners IIa transfer $£ 100$ to the capitalist households IIa.

\begin{tabular}{cr|lr}
\multicolumn{4}{c}{ I. Means of production } \\
\hline \multicolumn{4}{c}{ Firms I } \\
\hline$M$ & 1000 & $M$ & 1000 \\
$M p$ & 4000 & $M p_{1}$ & 4000 \\
& & $Q_{1}$ & 0 \\
& & $W_{1}$ & 0
\end{tabular}

\begin{tabular}{cr|lr}
\multicolumn{4}{c}{ IIa. Subsistence goods (necessaries) } \\
\hline \multicolumn{4}{c}{ Firms IIa } \\
\hline $\boldsymbol{M}$ & $\mathbf{3 0 0}$ & $M$ & 300 \\
$\mathrm{Sg}$ & 300 & $M p_{2 a}$ & 1600 \\
$\mathrm{Mp}$ & 1600 & $\boldsymbol{Q}_{2 a}$ & 300 \\
& & $W_{2 a}$ & 0
\end{tabular}

\begin{tabular}{lr|lr}
\multicolumn{4}{c}{ IIb. Luxury goods } \\
\hline \multicolumn{4}{c}{ Firms IIb } \\
\hline$M$ & 100 & $M$ & 200 \\
$L g$ & 200 & $M p_{2 b}$ & 400 \\
$M p$ & 400 & $Q_{2 b}$ & 100 \\
& & $W_{2 b}$ & 0
\end{tabular}
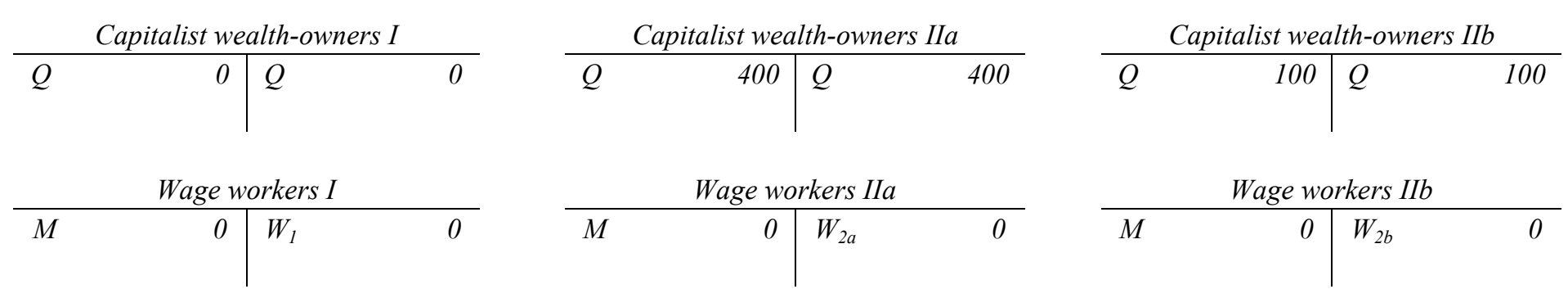

\begin{tabular}{lr|ll}
\multicolumn{4}{c}{ Capitalist Households I } \\
\hline$M$ & 0 & $C$ & 1000 \\
$Q$ & 0 & \\
$\mathrm{Sg}$ & 600 & \\
$\mathrm{Lg}$ & 400 & \\
\multicolumn{4}{c}{ Working Households I } \\
\hline $\mathrm{Sg}$ & 1000 & $\mathrm{C}$ & 1000
\end{tabular}

\begin{tabular}{cr|ll}
\multicolumn{5}{c}{ Capitalist Households IIa } \\
$\boldsymbol{M}$ & $\mathbf{1 0 0}$ & C & 400 \\
$\mathbf{Q}$ & & & \\
& & \\
& & \\
\multicolumn{4}{c}{ Working Households IIa } \\
\hline Sg & 400 & C & 400
\end{tabular}

\begin{tabular}{rr|ll}
\multicolumn{5}{c}{ Capitalist Households IIb } \\
\hline & 100 & C & 100 \\
& & & \\
\multicolumn{4}{c}{ Working Households IIb } \\
\hline $\mathrm{Sg}$ & 100 & $\mathrm{C}$ & 100
\end{tabular}


(22) Capitalist households IIa buy luxury goods for $£ 100$ from firms IIb.

\begin{tabular}{cr|lr}
\multicolumn{4}{c}{ I. Means of production } \\
\hline \multicolumn{4}{c}{ Firms I } \\
\hline$M$ & 1000 & $M$ & 1000 \\
$M p$ & 4000 & $M p_{1}$ & 4000 \\
& & $Q_{1}$ & 0 \\
& & $W_{1}$ & 0
\end{tabular}

\begin{tabular}{cr|lr}
\multicolumn{4}{c}{ IIa. Subsistence goods (necessaries) } \\
\hline \multicolumn{4}{c}{ Firms IIa } \\
\hline $\boldsymbol{M}$ & 300 & $M$ & 300 \\
$\mathrm{Sg}$ & 300 & $M p_{2 a}$ & 1600 \\
$\mathrm{Mp}$ & 1600 & $Q_{2 a}$ & 300 \\
& & $W_{2 a}$ & 0
\end{tabular}

\begin{tabular}{lr|lr}
\multicolumn{4}{c}{ IIb. Luxury goods } \\
\hline \multicolumn{4}{c}{ Firms IIb } \\
\hline $\boldsymbol{M}$ & $\mathbf{2 0 0}$ & $M$ & 200 \\
$\boldsymbol{L g}$ & $\mathbf{1 0 0}$ & $M p_{2 b}$ & 400 \\
$M p$ & 400 & $Q_{2 b}$ & 100 \\
& & $W_{2 b}$ & 0
\end{tabular}
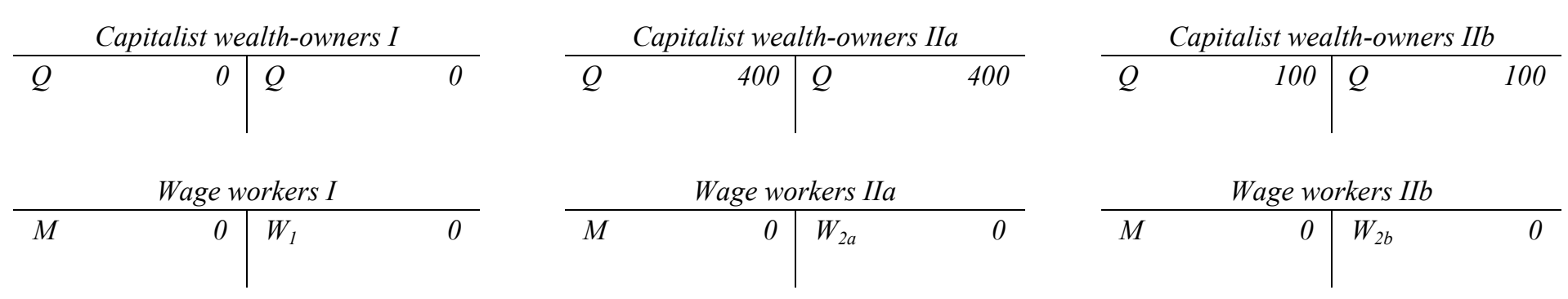

\begin{tabular}{lr|ll}
\multicolumn{5}{c}{ Capitalist Households I } \\
\hline$M$ & 0 & $C$ & 1000 \\
$Q$ & 0 & & \\
$\mathrm{Sg}$ & 600 & \\
$\mathrm{Lg}$ & 400 & \\
\multicolumn{4}{c}{ Working Households I } \\
\hline $\mathrm{Sg}$ & 1000 & $\mathrm{C}$ & 1000
\end{tabular}

\begin{tabular}{lr|ll}
\multicolumn{5}{c}{ Capitalist Households IIa } \\
$\boldsymbol{M}$ & $\boldsymbol{0}$ & C & 400 \\
$Q$ & 300 & & \\
$\boldsymbol{L g}$ & $\mathbf{1 0 0}$ & \\
& & & \\
\multicolumn{4}{c}{ Working Households IIa } \\
\hline Sg & 400 & C & 400
\end{tabular}

\begin{tabular}{rr|ll}
\multicolumn{5}{c}{ Capitalist Households IIb } \\
\hline & 100 & C & 100 \\
& & & \\
\multicolumn{4}{c}{ Working Households IIb } \\
\hline $\mathrm{Sg}$ & 100 & $\mathrm{C}$ & 100
\end{tabular}


(23) Firms IIa transfer the capital income for $£ 60$ to wealth-owners IIa. And firms IIb transfer the capital income for $£ 60$ to wealthowners IIb. In either case the firms transfer the capital income before having moneyed their profit.

\begin{tabular}{lr|lr}
\multicolumn{4}{c}{ I. Means of production } \\
\hline \multicolumn{4}{c}{ Firms I } \\
\hline$M$ & 1000 & $M$ & 1000 \\
$M p$ & 4000 & $M p_{1}$ & 4000 \\
& & $Q_{1}$ & 0 \\
& & $W_{1}$ & 0
\end{tabular}

\begin{tabular}{cr|lr}
\multicolumn{4}{c}{ IIa. Subsistence goods (necessaries) } \\
\hline \multicolumn{4}{c}{ Firms IIa } \\
\hline $\boldsymbol{M}$ & $\mathbf{2 4 0}$ & $M$ & 300 \\
$\mathrm{Sg}$ & 300 & $M p_{2 a}$ & 1600 \\
$\mathrm{Mp}$ & 1600 & $\boldsymbol{Q}_{2 a}$ & $\mathbf{2 4 0}$ \\
& & $W_{2 a}$ & 0
\end{tabular}

\begin{tabular}{lr|lr}
\multicolumn{4}{c}{ IIb. Luxury goods } \\
\hline \multicolumn{4}{c}{ Firms IIb } \\
\hline $\boldsymbol{M}$ & $\mathbf{1 4 0}$ & $M$ & 200 \\
$\mathrm{Lg}$ & 100 & $\mathrm{Mp} p_{2 b}$ & 400 \\
$\mathrm{Mp}$ & 400 & $\boldsymbol{Q}_{2 b}$ & 40 \\
& & $W_{2 b}$ & 0
\end{tabular}
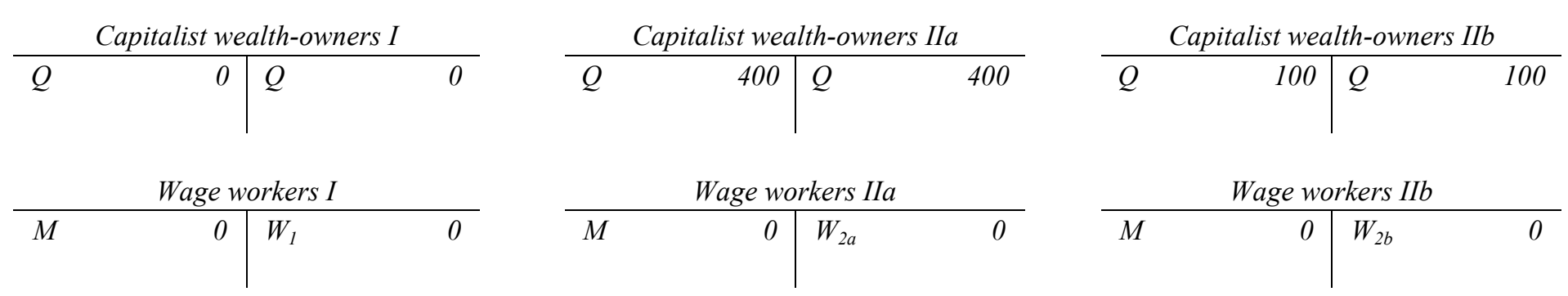

\begin{tabular}{lr|ll}
\multicolumn{5}{c}{ Capitalist Households I } \\
\hline$M$ & 0 & $C$ & 1000 \\
$Q$ & 0 & & \\
$S g$ & 600 & \\
$L g$ & 400 & \\
\multicolumn{4}{c}{ Working Households I } \\
\hline$S g$ & 1000 & $C$ & 1000
\end{tabular}

\begin{tabular}{lr|ll}
\multicolumn{4}{c}{ Capitalist Households IIa } \\
$\mathbf{M}$ & $\mathbf{6 0}$ & $\mathrm{C}$ & 400 \\
$\boldsymbol{Q}$ & 240 & & \\
$\mathrm{Lg}$ & 100 & \\
& & \\
\multicolumn{4}{c}{ Working Households IIa } \\
\hline $\mathrm{Sg}$ & 400 & $\mathrm{C}$ & 400
\end{tabular}

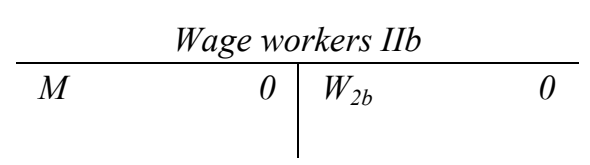

\begin{tabular}{lr|ll}
\multicolumn{4}{c}{ Capitalist Households IIb } \\
\hline $\boldsymbol{Q}$ & $\mathbf{6 0}$ & C & 100 \\
& $\mathbf{4 0}$ & & \\
& & &
\end{tabular}

\begin{tabular}{cc|ll}
\multicolumn{4}{c}{ Working Households IIb } \\
\hline Sg & 100 & C & 100
\end{tabular}


(24) Wealth-owners IIa transfer $£ 60$ to capitalist households IIa. And wealth-owners IIb transfer $£ 60$ to capitalist households IIb.

\begin{tabular}{cr|lr}
\multicolumn{4}{c}{ I. Means of production } \\
\hline \multicolumn{4}{c}{ Firms I } \\
\hline$M$ & 1000 & $M$ & 1000 \\
$M p$ & 4000 & $M p_{1}$ & 4000 \\
& & $Q_{1}$ & 0 \\
& & $W_{1}$ & 0
\end{tabular}

\begin{tabular}{cr|lr}
\multicolumn{4}{c}{ IIa. Subsistence goods (necessaries) } \\
\hline \multicolumn{4}{c}{ Firms IIa } \\
\hline $\boldsymbol{M}$ & $\mathbf{2 4 0}$ & $M$ & 300 \\
$\mathrm{Sg}$ & 300 & $M p_{2 a}$ & 1600 \\
$\mathrm{Mp}$ & 1600 & $\boldsymbol{Q}_{2 a}$ & $\mathbf{2 4 0}$ \\
& & $W_{2 a}$ & 0
\end{tabular}

\begin{tabular}{lr|lr}
\multicolumn{4}{c}{ IIb. Luxury goods } \\
\hline \multicolumn{4}{c}{ Firms IIb } \\
\hline $\boldsymbol{M}$ & $\mathbf{1 4 0}$ & $M$ & 200 \\
$\mathrm{Lg}$ & 100 & $M p_{2 b}$ & 400 \\
$\mathrm{Mp}$ & 400 & $\boldsymbol{Q}_{2 b}$ & 40 \\
& & $W_{2 b}$ & 0
\end{tabular}
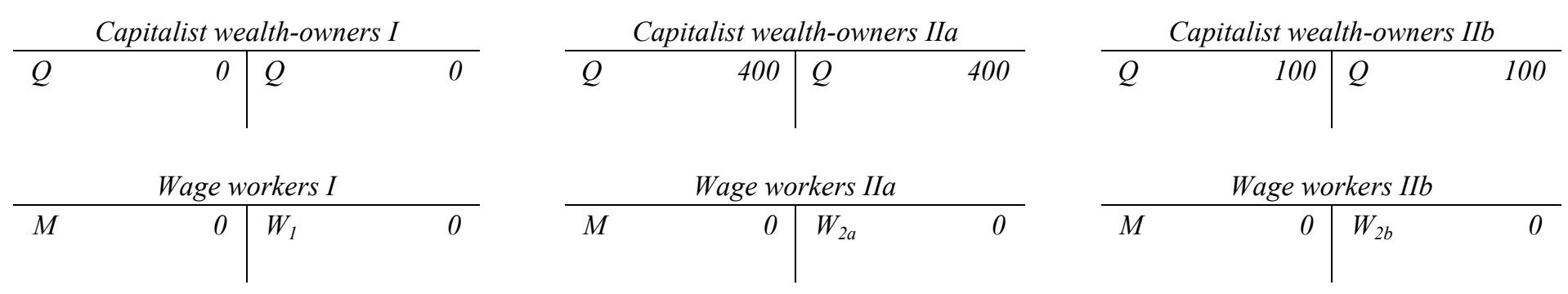

\begin{tabular}{lr|ll}
\multicolumn{5}{c}{ Capitalist Households I } \\
\hline$M$ & 0 & $C$ & 1000 \\
$Q$ & 0 & \\
$\mathrm{Sg}$ & 600 & \\
$\mathrm{Lg}$ & 400 & \\
\multicolumn{4}{c}{ Working Households I } \\
\hline $\mathrm{Sg}$ & 1000 & $\mathrm{C}$ & 1000
\end{tabular}

\begin{tabular}{lr|ll}
\multicolumn{4}{c}{ Capitalist Households IIa } \\
$\boldsymbol{M}$ & $\mathbf{6 0}$ & $\mathrm{C}$ & 400 \\
$\boldsymbol{Q}$ & $\mathbf{2 4 0}$ & & \\
$\mathrm{Lg}$ & 100 & \\
& & & \\
\multicolumn{4}{c}{ Working Households IIa } \\
\hline $\mathrm{Sg}$ & 400 & $\mathrm{C}$ & 400
\end{tabular}

\begin{tabular}{lr|ll}
\multicolumn{5}{c}{ Capitalist Households IIb } \\
$\mathbf{M}$ & $\mathbf{6 0}$ & $\mathrm{C}$ & 100 \\
$\mathbf{Q}$ & & & \\
& & & \\
\multicolumn{4}{c}{ Working Households IIb } \\
\hline $\mathrm{Sg}$ & 100 & $\mathrm{C}$ & 100
\end{tabular}


(25) Capitalist households IIa buy luxury goods for $£ 60$ from firms IIb. And capitalist households IIb buy necessaries for $£ 60$ from firms IIa.

\begin{tabular}{lr|lr}
\multicolumn{4}{c}{ I. Means of production } \\
\hline \multicolumn{4}{c}{ Firms I } \\
\hline$M$ & 1000 & $M$ & 1000 \\
$M p$ & 4000 & $M p_{1}$ & 4000 \\
& & $Q_{1}$ & 0 \\
& & $W_{1}$ & 0
\end{tabular}

\begin{tabular}{lr|lr}
\multicolumn{4}{c}{ IIa. Subsistence goods (necessaries) } \\
\hline \multicolumn{4}{c}{ Firms IIa } \\
\hline $\boldsymbol{M}$ & $\mathbf{3 0 0}$ & $M$ & 300 \\
$\mathbf{S g}$ & $\mathbf{2 4 0}$ & $M p_{2 a}$ & 1600 \\
$\mathrm{Mp}$ & 1600 & $Q_{2 a}$ & 240 \\
& & $W_{2 a}$ & 0
\end{tabular}

\begin{tabular}{lr|lr}
\multicolumn{4}{c}{ IIb. Luxury goods } \\
\hline \multicolumn{4}{c}{ Firms IIb } \\
\hline $\boldsymbol{M}$ & $\mathbf{2 0 0}$ & $M$ & 200 \\
$\boldsymbol{L g}$ & $\mathbf{4 0}$ & $\mathrm{Mp} p_{2 b}$ & 400 \\
$M p$ & 400 & $Q_{2 b}$ & 40 \\
& & $W_{2 b}$ & 0
\end{tabular}
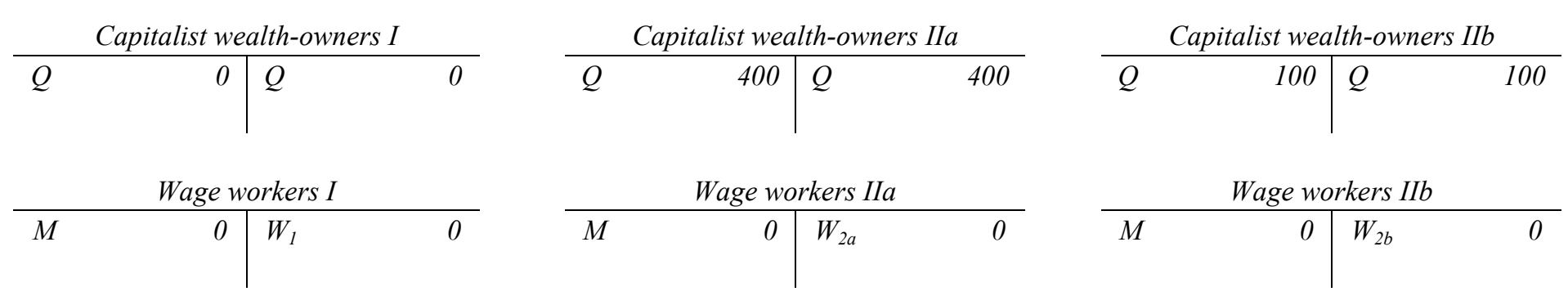

\begin{tabular}{lr|ll}
\multicolumn{5}{c}{ Capitalist Households I } \\
\hline$M$ & 0 & $C$ & 1000 \\
$Q$ & 0 & & \\
$\mathrm{Sg}$ & 600 & \\
$\mathrm{Lg}$ & 400 & \\
\multicolumn{4}{c}{ Working Households I } \\
\hline $\mathrm{Sg}$ & 1000 & $\mathrm{C}$ & 1000
\end{tabular}

\begin{tabular}{lr|ll}
\multicolumn{4}{c}{ Capitalist Households IIa } \\
$\mathbf{M}$ & $\mathbf{0}$ & C & 400 \\
$Q$ & 240 & & \\
$\mathbf{L g}$ & $\mathbf{1 6 0}$ & \\
& & \\
\multicolumn{4}{c}{ Working Households IIa } \\
\hline Sg & 400 & C & 400
\end{tabular}

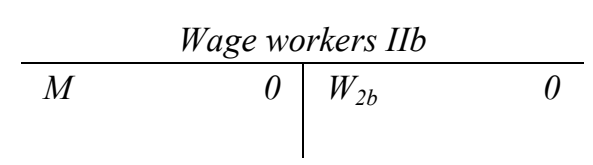

\begin{tabular}{lr|lr}
\multicolumn{4}{c}{ Capitalist Households IIb } \\
\hline $\boldsymbol{0}$ & $\mathbf{0}$ & C & 100 \\
$Q$ & 40 & & \\
$\mathbf{S g}$ & $\mathbf{6 0}$ & &
\end{tabular}

\begin{tabular}{cc|ll}
\multicolumn{4}{c}{ Working Households IIb } \\
\hline Sg & 100 & C & 100
\end{tabular}


(26) Firms IIa transfer the capital income for $£ 240$ to wealth-owners IIa. And firms IIb transfer the capital income for $£ 40$ to wealth-owners IIb. In either case the firms transfer the capital income before having moneyed their profit.

\begin{tabular}{lr|lr}
\multicolumn{4}{c}{ I. Means of production } \\
\hline \multicolumn{4}{c}{ Firms I } \\
\hline$M$ & 1000 & $M$ & 1000 \\
$M p$ & 4000 & $M p_{1}$ & 4000 \\
& & $Q_{1}$ & 0 \\
& & $W_{1}$ & 0
\end{tabular}

\begin{tabular}{cr|lr}
\multicolumn{4}{c}{ IIa. Subsistence goods (necessaries) } \\
\hline \multicolumn{4}{c}{ Firms IIa } \\
\hline $\boldsymbol{M}$ & $\mathbf{6 0}$ & $M$ & 300 \\
$\mathrm{Sg}$ & 240 & $M p_{2 a}$ & 1600 \\
$\mathrm{Mp}$ & 1600 & $\boldsymbol{Q}_{2 a}$ & $\boldsymbol{0}$ \\
& & $W_{2 a}$ & 0
\end{tabular}

\begin{tabular}{lr|lr}
\multicolumn{4}{c}{ IIb. Luxury goods } \\
\hline \multicolumn{4}{c}{ Firms IIb } \\
\hline $\boldsymbol{M}$ & $\mathbf{1 6 0}$ & $M$ & 200 \\
$\mathrm{Lg}$ & 40 & $\mathrm{Mp} p_{2 b}$ & 400 \\
$M p$ & 400 & $\boldsymbol{Q}_{2 b}$ & $\mathbf{0}$ \\
& & $W_{2 b}$ & 0
\end{tabular}
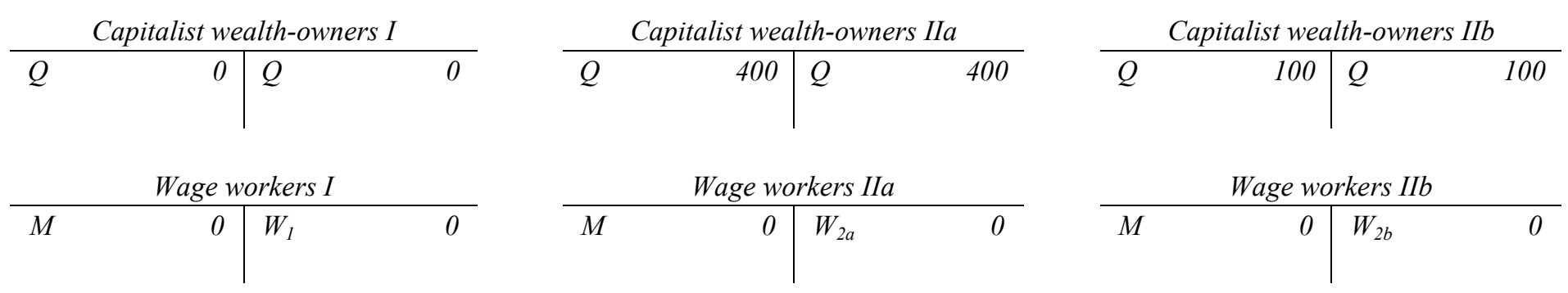

\begin{tabular}{lr|ll}
\multicolumn{5}{c}{ Capitalist Households I } \\
\hline$M$ & 0 & $C$ & 1000 \\
$Q$ & 0 & & \\
$\mathrm{Sg}$ & 600 & \\
$\mathrm{Lg}$ & 400 & \\
\multicolumn{4}{c}{ Working Households I } \\
\hline $\mathrm{Sg}$ & 1000 & $\mathrm{C}$ & 1000
\end{tabular}

\begin{tabular}{lr|ll}
\multicolumn{4}{c}{ Capitalist Households IIa } \\
$\mathbf{M}$ & $\mathbf{2 4 0}$ & $\mathrm{C}$ & 400 \\
$\boldsymbol{Q}$ & $\mathbf{0}$ & & \\
$\mathrm{Lg}$ & 160 & \\
& & & \\
\multicolumn{4}{c}{ Working Households IIa } \\
\hline $\mathrm{Sg}$ & 400 & $\mathrm{C}$ & 400
\end{tabular}

\begin{tabular}{lr|ll}
\multicolumn{5}{c}{ Capitalist Households IIb } \\
$\boldsymbol{M}$ & $\mathbf{4 0}$ & C & 100 \\
$\boldsymbol{Q}$ & $\boldsymbol{0}$ & & \\
$\mathrm{Sg}$ & 60 & &
\end{tabular}

\begin{tabular}{cc|ll}
\multicolumn{4}{c}{ Working Households IIb } \\
\hline Sg & 100 & C & 100
\end{tabular}


(27) Wealth-owners IIa transfer $£ 240$ to capitalist households IIa. And wealth-owners IIb transfer $£ 40$ to capitalist households IIb. End of circulation process of wealth-owners IIa and IIb.

\begin{tabular}{lr|lr}
\multicolumn{4}{c}{ I. Means of production } \\
\hline \multicolumn{4}{c}{ Firms I } \\
\hline$M$ & 1000 & $M$ & 1000 \\
$M p$ & 4000 & $M p_{1}$ & 4000 \\
& & $Q_{1}$ & 0 \\
& & $W_{1}$ & 0
\end{tabular}

\begin{tabular}{cr|lr}
\multicolumn{4}{c}{ IIa. Subsistence goods (necessaries) } \\
\hline \multicolumn{4}{c}{ Firms IIa } \\
\hline $\boldsymbol{M}$ & $\mathbf{6 0}$ & $M$ & 300 \\
$\mathrm{Sg}$ & 240 & $M p_{2 a}$ & 1600 \\
$\mathrm{Mp}$ & 1600 & $\boldsymbol{Q}_{2 a}$ & $\boldsymbol{0}$ \\
& & $W_{2 a}$ & 0
\end{tabular}

\begin{tabular}{lr|lr}
\multicolumn{4}{c}{ IIb. Luxury goods } \\
\hline \multicolumn{4}{c}{ Firms IIb } \\
\hline $\boldsymbol{M}$ & $\mathbf{1 6 0}$ & $M$ & 200 \\
$\mathrm{Lg}$ & 40 & $\mathrm{Mp} p_{2 b}$ & 400 \\
$M p$ & 400 & $\boldsymbol{Q}_{2 b}$ & $\mathbf{0}$ \\
& & $W_{2 b}$ & 0
\end{tabular}
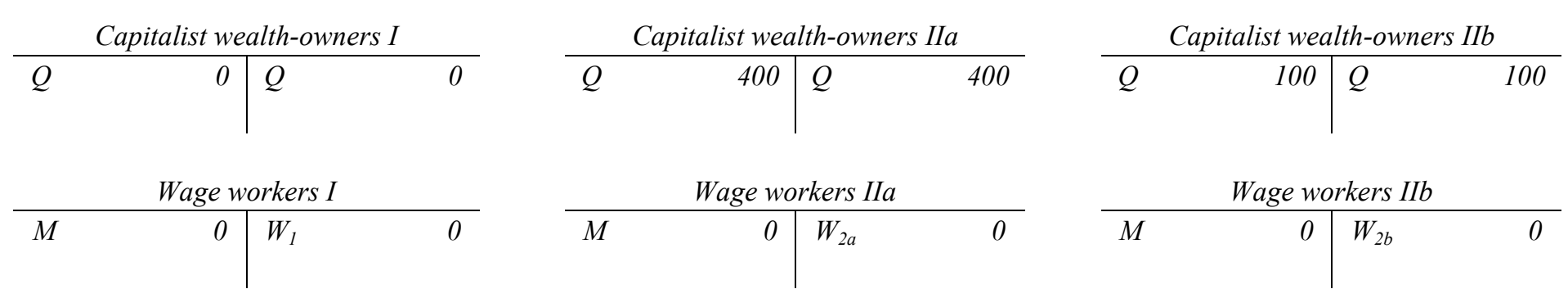

\begin{tabular}{lr|ll}
\multicolumn{5}{c}{ Capitalist Households I } \\
\hline$M$ & 0 & $C$ & 1000 \\
$Q$ & 0 & & \\
$S g$ & 600 & \\
$L g$ & 400 & \\
\multicolumn{4}{c}{ Working Households I } \\
\hline$S g$ & 1000 & C & 1000
\end{tabular}

\begin{tabular}{lr|ll}
\multicolumn{4}{c}{ Capitalist Households IIa } \\
$\mathbf{M}$ & $\mathbf{2 4 0}$ & $\mathrm{C}$ & 400 \\
$\boldsymbol{Q}$ & $\mathbf{0}$ & & \\
$\mathrm{Lg}$ & 160 & \\
& & & \\
\multicolumn{4}{c}{ Working Households IIa } \\
\hline $\mathrm{Sg}$ & 400 & $\mathrm{C}$ & 400
\end{tabular}

\begin{tabular}{lr|ll}
\multicolumn{5}{c}{ Capitalist Households IIb } \\
$\boldsymbol{M}$ & $\mathbf{4 0}$ & C & 100 \\
$\boldsymbol{Q}$ & $\boldsymbol{0}$ & & \\
$\mathrm{Sg}$ & 60 & &
\end{tabular}

\begin{tabular}{cc|ll}
\multicolumn{4}{c}{ Working Households IIb } \\
\hline Sg & 100 & C & 100
\end{tabular}


(28) Capitalist households IIa buy necessaries for $£ 240$ from firms IIb. And capitalist households IIb buy luxury goods for $£ 240$ from firms IIb. End of circulation process of firms IIa and capitalists households IIa. And end of circulation process of firms IIb and capitalist households IIb

\begin{tabular}{cr|lr}
\multicolumn{4}{c}{ I. Means of production } \\
\hline \multicolumn{4}{c}{ Firms I } \\
\hline$M$ & 1000 & $M$ & 1000 \\
$M p$ & 4000 & $M p_{1}$ & 4000 \\
& & $Q_{1}$ & 0 \\
& & $W_{I}$ & 0
\end{tabular}
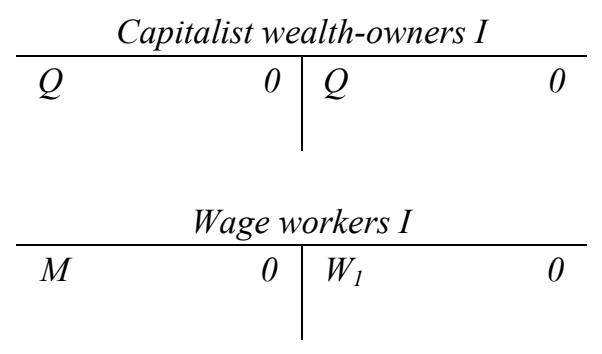

\begin{tabular}{lr|ll}
\multicolumn{4}{c}{ Capitalist Households I } \\
\hline$M$ & 0 & $C$ & 1000 \\
$Q$ & 0 & & \\
$S g$ & 600 & & \\
$L g$ & 400 & & \\
\multicolumn{4}{c}{ Working Households I } \\
\hline$S g$ & 1000 & C & 1000
\end{tabular}

IIa. Subsistence goods (necessaries)

\begin{tabular}{lr|lr}
\multicolumn{4}{c}{ Firms IIa } \\
\hline $\boldsymbol{M}$ & $\mathbf{3 0 0}$ & $M$ & 300 \\
$\boldsymbol{S g}$ & $\boldsymbol{0}$ & $M p_{2 a}$ & 1600 \\
$\mathrm{Mp}$ & 1600 & $Q_{2 a}$ & 0 \\
& & $W_{2 a}$ & 0
\end{tabular}
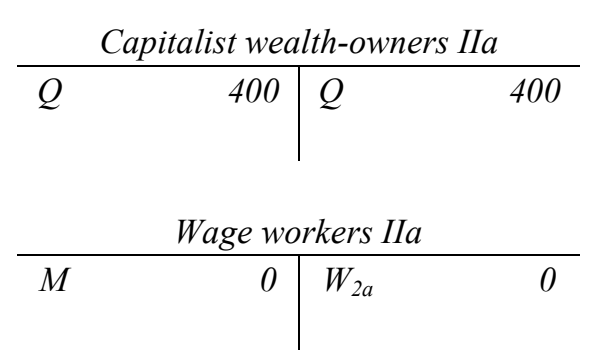

IIb. Luxury goods

\begin{tabular}{lr|lr}
\multicolumn{4}{c}{ Firms $I I b$} \\
\hline $\boldsymbol{M}$ & $\mathbf{2 0 0}$ & $M$ & 200 \\
$\boldsymbol{L g}$ & $\boldsymbol{0}$ & $M p_{2 b}$ & 400 \\
$M p$ & 400 & $Q_{2 b}$ & 0 \\
& & $W_{2 b}$ & 0
\end{tabular}

\begin{tabular}{ll|ll}
\multicolumn{4}{c}{ Capitalist wealth-owners IIb } \\
\hline$Q$ & 100 & $Q$ & 100
\end{tabular}

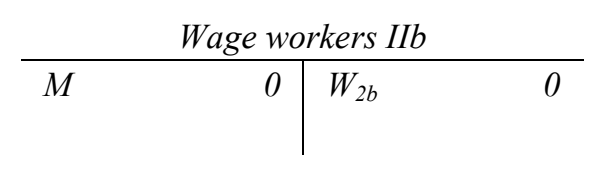

Capitalist Households IIb

\begin{tabular}{|c|c|c|c|c|c|c|c|}
\hline \multicolumn{4}{|c|}{ Capitalist Households IIa } & \multicolumn{4}{|c|}{ Capitalist Households IIb } \\
\hline$M$ & 0 & $C$ & 400 & $M$ & 0 & $C$ & 100 \\
\hline$Q$ & 0 & & & $Q$ & 0 & & \\
\hline$L g$ & 160 & & & $S g$ & 60 & & \\
\hline$S g$ & 240 & & & $L g$ & 40 & & \\
\hline
\end{tabular}

\begin{tabular}{cc|cc}
\multicolumn{4}{c}{ Working Households IIa } \\
\hline $\mathrm{Sg}$ & 400 & $\mathrm{C}$ & 400
\end{tabular}

\begin{tabular}{ll|ll}
\multicolumn{4}{c}{ Working Households IIb } \\
\hline Sg & 100 & C & 100
\end{tabular}


(29) Firms I by from themselves means of production for $£ 4000$. End of the circulation process of firms I.

\begin{tabular}{lr|lr}
\multicolumn{4}{c}{ I. Means of production } \\
\hline \multicolumn{4}{c}{ Firms I } \\
\hline$M$ & 1000 & $M$ & 1000 \\
$M \boldsymbol{p}$ & $\boldsymbol{0}$ & $M p_{1}$ & 4000 \\
$\boldsymbol{M} \boldsymbol{p}_{1}$ & $\mathbf{4 0 0 0}$ & $Q_{1}$ & 0 \\
& & $W_{1}$ & 0
\end{tabular}

\begin{tabular}{lr|lr}
\multicolumn{4}{c}{ IIa. Subsistence goods (necessaries) } \\
\hline \multicolumn{4}{c}{ Firms IIa } \\
\hline$M$ & 300 & $M$ & 300 \\
$S g$ & 0 & $M p_{2 a}$ & 1600 \\
$M p$ & 1600 & $Q_{2 a}$ & 0 \\
& & $W_{2 a}$ & 0
\end{tabular}

\begin{tabular}{lr|lr}
\multicolumn{4}{c}{ IIb. Luxury goods } \\
\hline \multicolumn{4}{c}{ Firms IIb } \\
\hline$M$ & 200 & $M$ & 200 \\
$\mathrm{Lg}$ & 0 & $M p_{2 b}$ & 400 \\
$M p$ & 400 & $Q_{2 b}$ & 0 \\
& & $W_{2 b}$ & 0
\end{tabular}
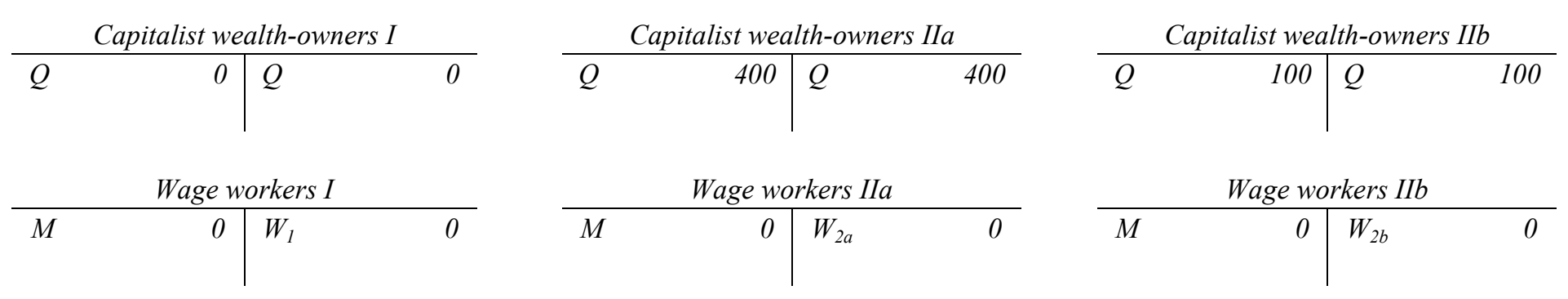

\begin{tabular}{|c|c|c|c|c|c|c|c|c|c|c|c|}
\hline \multicolumn{4}{|c|}{ Capitalist Households I } & \multicolumn{4}{|c|}{ Capitalist Households IIa } & \multicolumn{4}{|c|}{ Capitalist Households IIb } \\
\hline$M$ & 0 & $C$ & 1000 & $M$ & 0 & $C$ & 400 & $M$ & 0 & $C$ & 100 \\
\hline$Q$ & 0 & & & $Q$ & 0 & & & $Q$ & 0 & & \\
\hline$S g$ & 600 & & & $L g$ & 160 & & & $S g$ & 60 & & \\
\hline$L g$ & 400 & & & $S g$ & 240 & & & $L g$ & 40 & & \\
\hline \multicolumn{4}{|c|}{ Working Households I } & \multicolumn{4}{|c|}{ Working Households IIa } & \multicolumn{4}{|c|}{ Working Households IIb } \\
\hline$S g$ & 1000 & $C$ & 1000 & $S g$ & 400 & $C$ & 400 & $S g$ & 100 & $C$ & 100 \\
\hline
\end{tabular}


(30) The production decision of the firms conveys the contracting of the factors of production. Hence, the firms have to produce and monetize a new value-added that eventually allows them to finance the payment the money income of the factors of production. All the households consume the necessaries and the luxury commodities bought to the firms in sectors IIa and IIb.

\begin{tabular}{ll|ll}
\multicolumn{4}{c}{ I. Means of production } \\
\hline \multicolumn{4}{c}{ Firms I } \\
\hline$M$ & 1000 & $M$ & 1000 \\
$M p_{1}$ & 4000 & $M p_{1}$ & 4000 \\
$\boldsymbol{V A}$ & 2000 & $\boldsymbol{Q}_{1}$ & $\mathbf{1 0 0 0}$ \\
& & $\boldsymbol{W}_{\boldsymbol{1}}$ & $\mathbf{1 0 0 0}$
\end{tabular}

\begin{tabular}{lr|lr}
\multicolumn{4}{c}{ IIa. Subsistence goods (necessaries) } \\
\hline \multicolumn{4}{c}{ Firms IIa } \\
\hline$M$ & 300 & $M$ & 300 \\
$M p_{2 a}$ & 1600 & $M p_{2 a}$ & 1600 \\
$\boldsymbol{V A}$ & $\mathbf{8 0 0}$ & $\boldsymbol{Q}_{2 a}$ & 400 \\
& & $\boldsymbol{W}_{2 a}$ & 400
\end{tabular}

\begin{tabular}{ll|ll}
\multicolumn{4}{c}{ IIb. Luxury goods } \\
\hline \multicolumn{4}{c}{ Firms IIb } \\
\hline$M$ & 200 & $M$ & 200 \\
$M p_{2 b}$ & 400 & $M p_{2 b}$ & 400 \\
$\boldsymbol{V A}$ & $\mathbf{2 0 0}$ & $\boldsymbol{Q}_{2 \boldsymbol{b}}$ & $\mathbf{1 0 0}$ \\
& & $\boldsymbol{W}_{2 \boldsymbol{b}}$ & $\mathbf{1 0 0}$
\end{tabular}

\begin{tabular}{rr|lr}
\multicolumn{4}{c}{ Capitalist wealth-owners I } \\
\hline $\boldsymbol{Q}$ & $\mathbf{1 0 0 0}$ & $\boldsymbol{Q}$ & $\mathbf{1 0 0 0}$
\end{tabular}
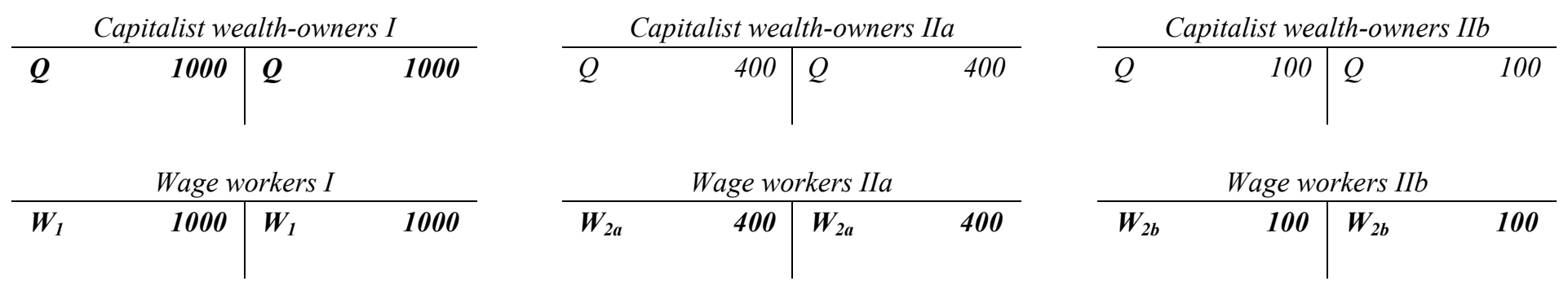

\begin{tabular}{|c|c|c|c|c|c|c|c|c|c|c|c|}
\hline \multicolumn{4}{|c|}{ Capitalist Households I } & \multicolumn{4}{|c|}{ Capitalist Households IIa } & \multicolumn{4}{|c|}{ Capitalist Households IIb } \\
\hline$M$ & 0 & $C$ & 1000 & $M$ & 0 & $C$ & 400 & $M$ & 0 & $C$ & 100 \\
\hline$Q$ & 1000 & & & $Q$ & 400 & & & $Q$ & 100 & & \\
\hline$S g$ & 0 & & & $S g$ & 0 & & & $S g$ & 0 & & \\
\hline$L g$ & 0 & & & $L g$ & 0 & & & $L g$ & 0 & & \\
\hline \multicolumn{4}{|c|}{ Working Households I } & \multicolumn{4}{|c|}{ Working Households IIa } & \multicolumn{4}{|c|}{ Working Households IIb } \\
\hline$M$ & 0 & $C$ & 1000 & $M$ & 0 & $C$ & 400 & $M$ & 0 & $C$ & 100 \\
\hline $\boldsymbol{W}$ & 1000 & & & $\boldsymbol{W}$ & 400 & & & $\boldsymbol{W}$ & 100 & & \\
\hline
\end{tabular}




\subsubsection{The production process}

(31) Production takes place in all sectors. At the end of the production process $(26)=(1)$ and the circulation process can start from the beginning at initial position (1).

\begin{tabular}{ll|ll}
\multicolumn{4}{c}{ I. Means of production } \\
\hline \multicolumn{4}{c}{ Firms I } \\
\hline$M$ & 1000 & $M$ & 1000 \\
$M \boldsymbol{M p}$ & $\mathbf{6 0 0 0}$ & $M p_{1}$ & 4000 \\
& & $Q_{1}$ & 1000 \\
& & $W_{I}$ & 1000
\end{tabular}

\begin{tabular}{cr|lr}
\multicolumn{4}{c}{ IIa. Subsistence goods (necessaries) } \\
\hline \multicolumn{4}{c}{ Firms IIa } \\
\hline$M$ & 300 & $M$ & 300 \\
Sg & 2400 & $M p_{2 a}$ & 1600 \\
& & $Q_{2 a}$ & 400 \\
& & $W_{2 a}$ & 400
\end{tabular}

\begin{tabular}{ll|lc}
\multicolumn{4}{c}{ IIb. Luxury goods } \\
\hline \multicolumn{4}{c}{ Firms IIb } \\
\hline$M$ & 200 & $M$ & 200 \\
$\boldsymbol{L g}$ & $\mathbf{6 0 0}$ & $M p_{2 b}$ & 400 \\
& & $Q_{2 b}$ & 100 \\
& & $W_{2 b}$ & 100
\end{tabular}
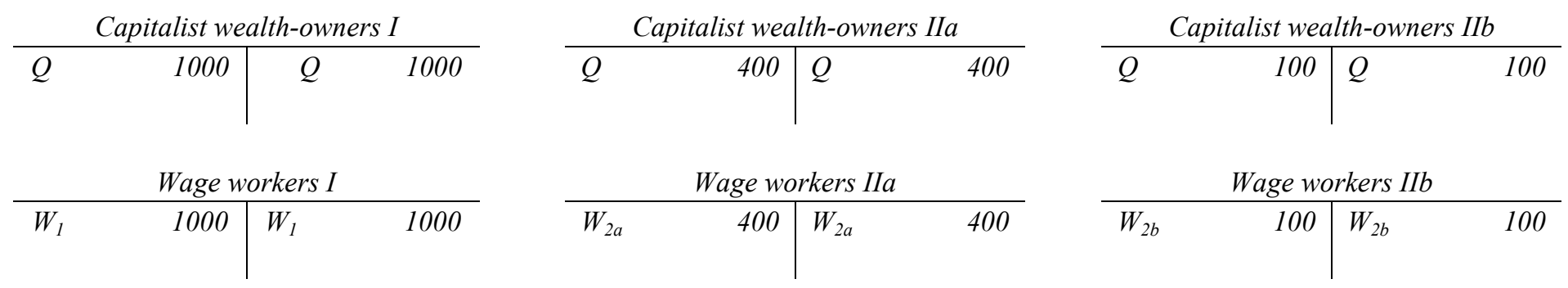

\begin{tabular}{rr|ll}
\multicolumn{4}{c}{ Capitalist Households I } \\
\hline$M$ & 0 & $C$ & 1000 \\
$Q$ & 1000 & & \\
\multicolumn{4}{c}{ Working Households I } \\
\hline$M$ & 0 & $C$ & 1000 \\
$W$ & 1000 & &
\end{tabular}

\begin{tabular}{cr|ll}
\multicolumn{4}{c}{ Capitalist Households IIa } \\
\hline$M$ & 0 & $C$ & 400 \\
$Q$ & 400 & & \\
\multicolumn{4}{c}{ Working Households IIa } \\
\hline$M$ & 0 & $C$ & 400 \\
$W$ & 400 & &
\end{tabular}

\begin{tabular}{cr|ll}
\multicolumn{4}{c}{ Capitalist Households IIb } \\
$M$ & 0 & $C$ & 100 \\
$Q$ & 100 & & \\
\multicolumn{4}{c}{ Working Households IIb } \\
\hline$M$ & 0 & $C$ & 100 \\
$W$ & 100 & &
\end{tabular}




\section{References}

Betz, K. (1987) "Das Kapital" als ökonomische Metatheorie. Berlin. Unpublished manuscript.

Bleaney, M. (1976) Undercomsumption Theories. A History and Critical Analysis. New York: International Publishers.

Cartelier, J. $(1986,1976)$ Excedente y reproducción. México: Fondo de Cultura Económica.

Deleplace, G., Nell, E. (eds.) (1996) Money in Motion: The Post Keynesian and Circulation Approaches. London and New York: Macmillan.

Hahn, F.H. (1982) Money and inflation. Oxford: Basil Blackwell.

Hahn, F.H. (1985) Macroeconomics, Growth and Stability. Cambridge, Mass.: The MIT Press.

Kalecki, M. (1974, 1956) Teoría de la dinámica económica. México: Fondo de Cultura Económica.

Kalecki, M. (1990) Collected Works of Michal Kalecki. Vol. I. Capitalism: Business Cycle and Full Employment. Edited by J. Osiatyński. Oxford: Clarendon Press.

Keynes, J.M. (1971, 1930) A Treatise on Money. Vol. I. The Pure Theory of Money. The Collected Writings of John Maynard Keynes. Vol. V. London and Basingstoke: Macmillan.

Keynes, J.M. (1973, 1936) General Theory of Employment, Interest and Money. The Collected Writings of John Maynard Keynes. Vol. VII. London and Basingstoke: Macmillan.

Leontief, W. (1928) Die Wirtschaft als Kreislauf, en: Archiv für Sozialwissenschaft und Sozialpolitik, 60 (3), 577-623.

Marx, K. (1983a; 1867, 1885, 1894) Das Kapital. Kritik der politischen Ökonomie. Marx Engels Werke. Berlin: Dietz Verlag. http://www.marxists.org/archive/ marx/works/1885.

Marx, K. (1983b, 1857-58) Grundrisse. Marx Engels Werke. Berlin: Dietz Verlag. http://www.marxists.org/archive/marx/works/1857/grundrisse

Marx, K. (1965, 1861-1863) Theorien über den Mehrwert. Marx Engels Werke. Berlin: Dietz Verlag. http://www.marxists.org/archive/marx/works/1863/theories-surplusvalue.

Menéndez, R. (1989) Die Organizationsstrukturen des Kreditgeldkapitalismus. Münster: Lit.

Quesnay, F. (1991) Physiocratie. Edición de J. Cartelier. París: Flammarion.

Riese, H. (1986) Theorie der Inflation. Tübingen: Mohr. 
Roldolsky, R. $(1979,1968)$ Génesis y estructura de El capital de Marx. México España Argentina Colombia: Siglo XXI Editores.

Samuelson, P.A. (1977, 1974) Marx as Mathematical Economist: Steady-State and Exponential Growth Equilibrium, en: The Collected Scientific Papers of Paul A. Samuelson, edited by Hiroakie Nagatani and Kate Crowley, vol. IV, 231-269. Cambridge (Mass.) London (England): The MIT Press.

Schmitt, B., Greppi, S. (1996) The National Economy Studied as a Whole: Aspects of Circular Flow Analysis in German Language, en: Deleplace/Nell (1996), capítulo 11, 341-364.

Smith, A. (1991, 1776) An Inquiry into the Nature and the Causes of the Wealth of Nations. New York: Everyman's Library.

Sraffa, P. (1960) Production of commodities by means of commodities. Cambridge: Cambridge University Press.

Snowdon, B., Vane, H. Wynarczyk, P. (1994) A Modern Guide to Macroeconomícs. An Introduction to Competing Schools of Thought. Aldershot (UK) Brookfield (VT, USA). Edward Elgar.

Sraffa, P. (1960) Production of Commodities by Means of Commodities. Cambridge: Cambridge University Press.

Stützel, W. (1958) Volkswirtschafliche Saldenmechanik. Tübingen: J.C.B. Mohr (Paul Siebeck).

Walras, L. (1954, 1926) Elements of Pure Economics. Traducción de William Jaffé. Homewood, Illinois: Richard D. Irwin, Inc. 